\title{
Assessing the societal benefits of river restoration using the ecosystem services approach
}

5

Jan E.Vermaat ${ }^{1,2}$, Alfred J. Wagtendonk ${ }^{3}$, Roy Brouwer ${ }^{3}$, Oleg Sheremet ${ }^{3}$, Erik Ansink $^{3,4}$, Tim Brockhoff ${ }^{3}$, Maarten Plug ${ }^{2,5}$, Seppo Hellsten ${ }^{5}$, Jukka Aroviita ${ }^{5}$, Luiza Tylec ${ }^{6}$, Marek Giełczewski ${ }^{6}$, Lukas Kohut ${ }^{7}$, Karel Brabec ${ }^{7}$, Jantine Haverkamp ${ }^{2,8}$, Michaela Poppe ${ }^{8}$, Kerstin Böck $^{8}$, Matthijs Coerssen ${ }^{2,9}$, Joel Segersten ${ }^{9}$, Daniel Hering ${ }^{10}$

10

${ }^{1}$ Department of Environmental Sciences, Norway’s University of Life Sciences, Frougnerbakken 3, 1430 Ås, Norway, jan.vermaat@nmbu.no,

2 previous address: Section Earth Sciences and Economics, Faculty of Earth and Life Sciences, VU University, The Netherlands

$15{ }^{3}$ Institute for Environmental Studies, VU University, De Boelelaan 1087, $1081 \mathrm{HV}$ Amsterdam, The Netherlands

${ }^{4}$ Department of Economic and Social History, Utrecht University, Drift 6, 3512 BS Utrecht, The Netherlands

${ }^{5}$ Finnish Environment Institute (SYKE), Freshwater Centre, Monitoring and Assessment

20 Unit, P.O. Box 413, FIN-90014 University of Oulu, Finland

${ }^{6}$ Division of Hydrology and Water Resources, Warsaw University of Life Sciences, ul. Nowoursynowska 159, 02-776 Warsaw, Poland

${ }^{7}$ Research Centre for Toxic Compounds in the Environment (RECETOX) Faculty of Science, Masaryk University Kamenice 753/5, pavilion A29, 62500 Brno, Czech Republic

$25{ }^{8}$ Institute of Hydrobiology and Aquatic Ecosystem Management, University of Natural Resources and Life Sciences Vienna (BOKU), Max-Emanuel-Straße 17, A-1180 Vienna, Austria.

${ }^{9}$ Department of Aquatic Sciences and Assessment, Swedish University of Agricultural Sciences (SLU), Uppsala, Sweden

$30{ }^{10}$ Department of Aquatic Ecology, University of Duisburg-Essen, D-45117 Essen, Germany 


\section{Abstract}

The success of river restoration was estimated using the ecosystem services approach. In eight pairs of restored-unrestored reaches and floodplains across Europe, we quantified provisioning (agricultural products, wood, reed for thatching, infiltrated drinking water), regulating (flooding

40 and drainage, nutrient retention, carbon sequestration) and cultural (recreational hunting and fishing, kayaking, biodiversity conservation, appreciation of scenic landscapes) services for separate habitats within each reach, and summed these to annual economic value normalised per reach area. We used locally available data and literature, did surveys among inhabitants and visitors, and used a range of economic methods (market value, shadow price, replacement cost, 45 avoided damage, willingness-to-pay survey, choice experiment) to provide final monetary service estimates. Total ecosystem service value was significantly increased in the restored reaches (difference $1400 \pm 600 €$ ha $^{-1} \mathrm{y}^{-1}$ (2500 minus 1100, $\mathrm{p}=0.03$, paired t-test). Removal of one extreme case did not affect this outcome. We analysed the relation between services delivered and with floodplain and catchment characteristics after reducing these 23 variables to four principal

50 components explaining $80 \%$ of the variance. Cultural and regulating services correlated positively with human population density, cattle density and agricultural $\mathrm{N}$ surplus in the catchment, but not with the fraction of arable land or forest, floodplain slope, mean river discharge, or GDP. Our interpretation is that landscape appreciation and flood risk alleviation are a function of human population density, but not wealth, in areas where dairy farming is the prime form of agriculture.

Key words: carbon sequestration, retention, sediment, nutrients, Europe, river corridor, wetlands, flood control, biodiversity, economic valuation, choice experiments, willingness-to-pay 
Over the past decades, rivers have been restored for a range of purposes, such as flood mitigation, habitat and biodiversity enhancement and water quality improvement (Bernard et al., 2005; Benayas et al., 2007; Jähnig et al., 2011). Purpose and success of restoration often have been reported with limited rigor (Bernhardt et al., 2005, Bernhardt \& Palmer, 2011; Jähnig et al., 2011), as in other ecosystems (Zedler \& Kercher, 2005; Benayas et al., 2007). In addition, indicators of success used vary widely, ranging from geomorphological elements in the floodplain landscape, and water quality parameters to presence of characteristic biota in different species groups as well as aggregate biodiversity indicators. This variation can be due to the purpose of restoration, the scale of the assessment, and the institutional context (Jähnig et al., 2011; Morandi et al., 2014; Hering et al., in revision, J. Appl Ecol). The combination of poor documentation and variable indicators is at odds with standards for study design (Underwood, 1996). It also complicates a comparative analysis across larger numbers of cases at a later stage (Benayas et al., 2007; Morandi et al., 2014), which is an important tool for policy evaluation (Turner et al., 2000).

This study is an attempt to carry out such an analysis across eight European rivers using the ecosystem services approach as an integrating framework (cf Acuna et al., 2013). We will first argue why the ecosystem services approach could be fit for this purpose and address the issue of spatial scale and resolution, then specify our underlying hypothesis on how ecosystem services

80 could be affected by river restoration and conclude with our research questions.

The concept of ecosystem services has been advocated by the by the Millennium Ecosystem Assessment (MEA, 2005) as a means to integrate all possible direct and indirect benefits that accrue from an ecosystem to human society, including those that are not straightforwardly monetized. It has been further developed into a well-specified typological catalogue with three main categories, i.e. provisioning, regulating and cultural services (e.g. Wallace, 2007; Bateman et al., 2010; Watson \& Albon, 2011; Weber, 2011; see below, methods section). The ecosystem services approach is applied increasingly (Fisher et al., 2009; report an exponential increase in publications) to include all these potential benefits in comprehensive decision-making and 90 planning efforts (e.g. Carpenter et al., 2009; Nelson et al., 2009; Bateman et al., 2010; De Groot et 
al., 2010; Acuna et al., 2013). Ecosystem services depend on a variety of intermediate ecosystem processes and states, but their societal value ultimately depends on the use (and non-use) by humans in their final form. A particular habitat can provide several services simultaneously, such as mineable sand, the retention of nutrients, the accumulation of carbon in wood, the excitement of angling, and the enjoyment of the scenic beauty of the riverine landscape. Briefly, our quantification was carried out in three steps. First, services in their final form (Wallace, 2007; Bateman et al., 2010), a form which is measurably beneficial to society and is not intermediate leading to yet another ecosystem process or service, are quantified in biophysical units. An example of a final regulating service is nutrient retention in $\mathrm{kg}$ of phosphorus retained $\mathrm{ha}^{-1} \mathrm{y}^{-1}$ ).

100 Then all final services are valued separately using a range of economical methods. Finally, these monetary values are summed for the ecosystem. Since restoration measures can affect a wide range of processes and conditions in river and floodplain, comprehensive evaluation of their success should integrate all aspects considered potential benefits to society. We understand that the summation of ecosystem services is essentially anthropocentric through its focus on societal 105 benefit (Westmann, 1977), but argue that the estimated economic value offers a useful though imperfect common yardstick, which is expressed in tangible units that are understandable to the general public and decision makers.

Ecosystem services quantification is spatially bound by the extent of the providing ecosystem, 110 which is inherently unspecific. River restoration efforts are geographically limited to banks and floodplains, but may still differ widely in spatial extent (Bernard et al., 2005). Overall, restoration is thought to be more successful when longer stretches of river are restored, and the landscape setting is incorporated, particularly for larger and longer-lived organisms, such as fish and macrophytes (e.g. Lorenz \& Feld, 2013). In contrast however, Hering et al. (in prep. J Appl Ecol)

115 observed that intensity of habitat modification in the restoration effort had a far more pronounced effect than extent of the restoration (i.e. km of river length restored). This suggests that intensity and extent of restoration are different dimensions, and that the landscape and catchment perspective is important. Most restoration projects (Bernhardt et al., 2005) are carried out at the reach scale (a length of several river widths up to $20 \mathrm{~km}$, Brierley and Fryirs, 2005), and the case 120 study sites in our project conformed to this (Muhar et al., introduction to this special issue). Reaches are viewed as comparatively homogeneous stretches of landscape in the river network 
draining a catchment (Skøien et al., 2003). Reach-scale floodplain stretches however consist of mosaics of different habitats, such as woodland, grassland, marshes, or gravel beds. Within-reach variability in these habitats can be considerable, and these different habitats can differ markedly in

125 service provision, such as sedimentation and nutrient retention (Olde-Venterink et al. 2006). Therefore, where reaches are the spatial unit of comparison, internal habitat constellation at the local scale, as well as the wider landscape and catchment geography, the regional scale, are important determinants of services potentially provided as well as of societal use.

130 Gilvear et al. (2013) stress that the 'degraded, unrestored' state is the result of previous, anthropogenic 'improvement', which also had a distinct, societally recognized purpose, such as drainage, flood protection and navigation. Only the policy perspective has changed with time, and restoration implies that a river has been converted into a state that more closely resembles a historical form and functioning, and is appreciated more highly. Therefore, a 'no measurable

135 effect' zero hypothesis is appropriate. The alternative hypothesis can be a compounding of regulating and cultural services, because specific restoration purposes often relate to these two categories (Bernhard et al., 2005; Jähnig et al., 2011). Overall, we expect that regulating as well as cultural services related to habitat structure and dynamics of the river channel and floodplain, including an appreciation of increased scenic beauty of the landscape, are enhanced by river

140 restoration at the reach scale. Our questions are: (1) Do we find significantly higher societal appreciation of restored as compared to unrestored reaches using an ex-post economic quantification of ecosystem services? (2) Is this difference related to regulating and cultural services? (3) Can we identify underlying geographic differences in the patterns of service provision and valuation for these Central and Northwestern European rivers?

\section{Methods}

\section{Studied reaches}

Seven out of the eight studied pairs of reaches (Fig. 1a, Table 1, see also Muhar et al., introduction

150 to this special issue) were studied in the field by two or more of our co-authors, often assisted by local colleagues. For the Skjernå in Denmark, we could depend on the exhaustive documentation of Dubgaard et al. (2005), which includes the economic assessment of cultural services (Table 1). 
The teams collected local information on all possible forms of ecosystem services provided by the river corridor in both the restored and unrestored reach. We assumed that the floodplain corresponded to the spatial extent of each river corridor and determined it with GIS from historical flood maps (see references in Table 1). River corridors of restored and unrestored reaches in a pair varied in length, area, and habitat provenance. We have not normalized habitat provenance to a standard proportion across all reaches (for example all normalized to $50 \%$ woodland, $40 \%$ grassland and $10 \%$ marshland) prior to our analyses, because restoration involves a purposeful

160 alteration of habitats, for example by the re-establishment of marshes and open water.

\section{Quantification of ecosystem services}

We applied the methodological framework of Vermaat et al. (2013), which allocates different habitat patches in a reach to uniformly classified units (EUNIS-CORINE, example in Fig 1b;

165 Davies et al., 2004) and accumulates the different services provided by each habitat unit in a reach (Table 2 lists all services quantified in this study). We first expressed all final services in biophysical units in the form they are utilized by society, then monetized these using one of several economic methods available (see below), and finally summed these per reach. Thus, our service accumulation is a simple summation of total ecosystem service delivery across habitats in a reach

170 as annualized monetary value (Fig. 3), which is normalized to reach area.

Environmental economists have developed a range of methods to estimate the economic value of ecosystem services (Bouma \& Van Beukering, 2015). They have reviewed applicability and error components (Brouwer et al., 1999, 2008; Turner et al., 2000; Brander et al., 2006; Bateman et al.,

175 2010; Watson and Albon, 2011), and have aggregated estimates derived from different methods (Dubgaard et al., 2005; Acuña et al., 2013, Martin-Lopez et al., 2014). We based our choice of method on a decision tree from DEFRA (2007), and data availability (Table 1 and 2, Fig. 2, Vermaat et al. 2013). Since we aimed to integrate over different services and compare between reaches, we chose to express all services in monetary units. We do not distinguish other value 180 domains for service appreciation beyond our monetary assessment. We have two reasons for this: First, we are convinced that a limitation to final provisioning, regulating or cultural final services should account for all underlying supporting services. This implies that a separate distinction of 'habitat provision' (De Groot et al., 2010) or the 'biophysical domain’ (Martin-Lopez et al., 2014) 
is redundant at the final service level as these are already included as supporting services

185 contributing to final services. Second, a monetary quantification may not grasp the fullness and diversity of societal appreciation (Westmann, 1977), but it does provide a harmonised means to compare, evaluate trade-offs, and inform policy makers. An overview of services evaluated and economic methods applied is given in Table 2. Reference to literature and further details on these methods can be found in Vermaat et al. (2013) and the case study reports (Table 1) available on the

190 project website (www.reformrivers.eu).

Local willingness-to-pay (wtp) surveys followed a general structure but were geared to the local conditions, pre-tested locally, and set in a choice-experiment design (Table 1). Each also included an open-ended wtp-question regarding river restoration. Where the choice experiments allowed

195 breakdown of the willingness to pay for restoration into separate components, we used the value reflecting non-use of biodiversity and/or scenic landscape beauty because we have separate estimates for recreational use. Other final services due to biodiversity, such as pollination or enhanced pest control (Cardinale et al., 2012), have not been quantified. Respondents have been classified as local inhabitants or tourists from elsewhere in- or outside the country. We consider

200 local respondents to represent the human population of the adjacent riparian administrative unit(s), which was municipality or one administrative level higher (Denmark, Poland). The percentage of cooperative respondents was included to correct the number of households and tourist visitors possibly willing to pay for river restoration. Since Dubgaard et al. (2005) used the value of the euro for the year 2000, it was adjusted by 1.45 to correspond to the August 2013 euro values

205 applied for all others in this study. For the sampling periods between April 2013 and September 2014 (Table 1) the value of the euro differed by $4 \%$ at most so we did not adjust it.

\section{Statistical analysis}

We quantified land use, intensity of agricultural use, human population density and economic

210 indicators of the upstream catchment of a reach from various European spatial databases (supplementary material table S1). Where relevant we included both the mean and standard deviation for each catchment variable. The difference in estimated value between restored and unrestored reaches was analysed with a paired t-test followed by linear regression of restored versus unrestored values, where a significant intercept and slope higher than 1 indicate that 215 restored and unrestored values differ. Robustness of the regression was inspected by the change in 
parameters after leaving out the most extreme data pair. We analysed the possible relationship between service delivery of a reach as dependent variable and reach land use, as well as catchment geographic data, as explanatory variables using a General Linear Model (GLM). We had no a priori assumptions on geographical hierarchy of the explanatory variables. Covariance among the possibly underlying geographic pattern in catchment (regional) and floodplain (local) variables was first addressed in a Principal Components Analysis (PCA). The significant principal components explaining more than $10 \%$ of the variance were used as explanatory covariates in a GLM-ANOVA with restored-unrestored as fixed factor. This assesses whether restoration has a significant impact on service delivery over and above the different covariates grasping

225 geographical variability at local reach and regional catchment scale. PCA and GLM were done with SPSS; exploratory data analysis was done with PAST (Hammer et al., 2001).

\section{Results}

230 Despite considerable variability in the relative importance of provisioning, cultural or regulating services among paired reaches (Fig. 3a, also fig S1), restored reaches and their floodplains provided a significantly higher total value. Also, higher values of unrestored reaches correlated with higher values of restored reaches, with the exception of the Becva (Fig. 3b). This river is an outlier because of the substantial and frequent flood damage (also in recent years; Kohut, 2014) in

235 the unrestored reach, which is largely prevented after restoration. The net sum of regulating services in this unrestored reach was negative, but its exclusion did not lead to a major change in outcome of the paired t-test (difference reduced from 1384 to $840 €, \mathrm{p}=0.04$ ).

The studied reaches and their catchments differed considerably in land use and human population

240 density (Fig. 4). Covariance among the 23 catchment and floodplain variables was reduced by retaining only the four principal components together explaining $80 \%$ of the total variance (Fig. 5a). Intensity of dairy farming and arable agriculture each correlated highly with a different principal component (respectively pc1 and pc2, Fig 5a). Both co-varied significantly with human population density and soil sealing in the catchment. Nitrogen surplus on agricultural land varied

245 parallel with livestock density (pc1). Nitrogen surplus on forested land appeared to correlate with $\%$ arable land, and was negatively correlated with total catchment area and total numbers of 
livestock in a catchment (pc2). GDP differed greatly among our study rivers, yet pc3 (which was correlated with GDP, data not shown) was not correlated with any ecosystem service. The pairs of restored-unrestored reaches plotted near to each other across the first two principal components

250 (Fig 5b), suggesting that the paired reaches indeed are comparable in floodplain and catchment geography.

Catchment and floodplain land use were related to ecosystem service delivery in a GLM-ANOVA with the four principal components as covariates (Table 3). Consistent with the paired t-test, but now without potential confounding from geographic floodplain and catchment variability, restoration had a significant effect on total service delivery and cultural services. We found a marginally significant effect $(\mathrm{p}<0.10)$ of restoration on regulating services. However, only cultural services co-varied significantly with pc1. Thus, cultural services are valued higher in areas of higher human population density and more intensive agriculture (pc1), rather than for example in

260 wealthier areas with higher GDP. GDP did not correlate significantly with the first two principal components. This corresponds with the absence of a significant relation between respondents' willingness to pay for river restoration and reported net monthly income (Fig. 6): we had to remove two outliers of the seven cases to find a positive relation as is typically found in valuation studies. The fact that respondents along the Becva are willing to pay considerably more, and those

265 along the Morrumsån much less suggests important site-specific factors. Along the Becva, inhabitants and visitors alike have lively memories of recent catastrophic floods and high expectations of the new floodplain landscape, which is frequently used. In stark contrast, the respondents along the Morrumsån appreciated only a limited tax increase for river restoration, and only $20 \%$ of the interviewed people were willing to cooperate.

\section{Discussion}

\section{Increased societal benefits due to river restoration}

275 Our analysis of ecosystem services indeed suggests that river restoration enhances societal benefits: averaged across all 8 rivers we found a significantly higher service delivery (Fig. 3, Table 3). This appears to be primarily due to an increase in cultural services, and less distinctly to an 
increase in regulating services (Table 3), whereas provisioning services were not affected by restoration. Our interpretation is that landscape appreciation and flood risk alleviation are a

280 function of human population density, but not wealth, in areas where dairy farming is the prime form of agriculture. At the same time, variability among rivers was substantial. In one case, the Finnish Vääräjoki, the restoration was limited to the stream bed but this led to a reduction of the already low agri- and silvicultural production (provisioning services), and it slightly enhanced flood risk via an increased frequency of ice dams on restored rapids. In another case, the Czech

285 Becva, agricultural provisioning value was nullified by the high risk of flood damage in the unrestored reach.

When we sought for underlying physical, or social geographic factors in floodplain and surrounding catchment characteristics, we found a distinct correspondence of higher societal

290 restoration benefits with a higher human population density and cattle density. Willingness to pay of the respondents as well as their net income and overall wealth expressed as GDP differed greatly among our study rivers, yet pc3 (which was correlated with GDP) was not correlated with any ecosystem service. We interpret this to imply that rather more people appreciate the enhanced cultural services provided by a restored reach, than that a more wealthy population is individually

295 willing to pay more for restoration, which is in line with findings of Brander et al. (2013). The correspondence of regulating and cultural services with pc1 suggests that restoration to a 'more natural' flooding regime of the corridor has led to an increased appreciation by inhabitants and tourists of the scenic beauty of these landscapes. This translated into increased revenues in the recreation sector, notably in the Narew, Regge, Vääräjoki, Skjernå and Morrumsån

300 (Supplementary material S2).

\section{Methodology, uncertainty and implications}

Since our aggregation across habitats and potential services uses a wide range of data sources and local as well as literature-based estimates, an estimate of potential systematic and random error is

305 difficult to give. Instead, we will briefly discuss several limitations and aspects of uncertainty related to our estimates. First, we have willingly restrained ourselves and used a single, convergent economic dimension of value for the reasons outline in the introduction. Second, some components of total ecosystem service delivery were not quantified (reduced downstream sedimentation, 
effects on hydropower delivery, pollination) or may have been overlooked. Others have been

310 estimated conservatively in a systematic way, so we probably have underestimated total ecosystem service delivery, but we see no reason that this may have been biased towards favouring restoration. Third, our selection of restored cases may have been subject to selection bias. Although this is hard to verify in a formal way (see Bernard et al., 2005), we may have unknowingly taken early 'easy success' cases. This calls for a cautious extrapolation of our

315 findings, with due attention to the specific services involved. Fourth, the net benefit accrues to different businesses or individuals in some cases, but to the common case of a nation or global humanity in other cases. For example, regulating services of a floodplain accrue to local farmers (nutrient provision), downstream communities (less flooding), the navigation (water level) or hydropower sector (increased reservoir life span), which is either national or property of larger

320 international consortia, or the global human population (climate mitigation). Where decisionmaking involves such different sectors and scales, the appropriate level for decision-making may well be national, or supranational (Van Teeffelen et al., 2014). This does not make our conclusion less opportune: river restoration appears economically beneficial to society.

325 We can ask whether our estimates appear meaningful compared to literature or local agricultural land prices. Our estimates of total ecosystem service delivery (median 1500, range $-1800-5800 €$ $\mathrm{ha}^{-1} \mathrm{y}^{-1}$ ) are comparable to those of Murray et al. (2009, for restored Mississippi floodplain habitats $\left(1000 € \mathrm{ha}^{-1} \mathrm{y}^{-1}\right)$, Brander et al. (2013, only regulating services of wetlands in agricultural land $600 € \mathrm{ha}^{-1} \mathrm{y}^{-1}$ compare Fig. 3), or Martin-Lopez et al. (2014, for the whole Cota Donana wetland 330 complex, including irrigated rice production and shrimp fisheries, $9000 € \mathrm{ha}^{-1} \mathrm{y}^{-1}$ ). Our comparison with local land rents suggests that the increase in value due to restoration, observed in six out of the eight cases, was about three times higher than land rent (Fig. 7, using the median ratio). With most provisioning and a limited part of the cultural services grasped in markets, profitability assessment of restoration should still involve a cost-benefit assessment including opportunity costs

335 of the alternatives for the decision maker as well as a conservative rate of interest and return period (Dubgaard et al., 2005). We have not included the cost here. Taken together, this suggests that our economic value estimates of societal benefits of restoration may not be exactly accurate reflections of total economic value, but do appear meaningful and reasonably within range. 


\section{Acknowledgements}

345 This paper is a contribution from the EU seventh framework funded research project REFORM (Grant Agreement 282656). We thank our colleagues in the project for the cooperative spirit, and for thinking through the most useful study design we could simply adopt, and Tom Buijse for his energetic project coordination.

\section{References}

Acuna V, Ramon Diez J, Flores L, Meleason M, Elosegi A, 2013. Does it make sense to restore rivers for their ecosystem services? J. Appl Ecol 50, 988-997.

355

Banaszuk P, Kamocki A, 2008. Effects of climatic fluctuations and land-use changes on the hydrology of temperate fluvigenous mire. Ecol. Engin. 32, 133-146.

Banaszuk P, Wysocka-Czubaszek A, Kondratiuk P, 2005. Spatial and temporal patterns of 360 groundwater chemistry in the rver riparian zone. Agric Ecosys Environ 107, 167-179.

Bateman IJ, Mace GM, Fezzi C, Atkinson G, Turner RK (2010) Economic analysis for ecosystem service assessments. Env Res Econ 48:177-218

365 Benayas JMR, Newton AC, Diaz A, Bullock JM, 2007. Enhancement of biodiversity and ecosystem services by ecological restoration: a meta-analysis. Science 325, 1121-1124

Bernhardt ES, Palmer MA, Allan JD, Alexander G, Barnas K, Brooks S, Carr J, Clayton S, Dahm C, Follstad-Shah J, Galat D, Gloss S, Goodwin P, Hart D, Hasset B, JenkinsonR, Katz S, Kodolf

370 GM, Lake PS, Lave R, Meyr JL, O’Donnell TK, Pagano L, Powell B, Sudduth E, 2005. Synthezising U.S. river restoration efforts. Science 308, 636-637.

Bernhardt ES, Palmer MA, 2011. River restoration: the fuzzy logic of repairing reaches to reverse catchment scale degradation. Ecol Applic 21, 1926-1931

Bonnie R, Carey M, Petsonk A, 2002. Protecting terrestrial ecosystems and the climate through a global carbon market. Phil Trans R Soc Lond. A 360, 1853-1873

Bouma JA, Van Beukering PJH, 2015. Ecosystem services - from concept to practice. Cambridge University Press, 267 pp.

Brander L, Vermaat JE Florax RJGM, 2006. The empirics of wetland valuation: a meta-analysis. Env Resource Econ 33:223-250

385 Brander L, Brouwer R, Wagtendonk A, 2013. Economic valuation of regulating services provided by wetlands in agricultural landscapes: A meta-analysis. Ecol Engin 56, 89-96. 
Brierley GJ, Fryirs KA, 2005. Geomorphology and river management: applications of the River Styles framework. Cambridge University Press

390

Brockhoff T, 2013. River restoration along the Regge - a comparative analysis of the effects of river restoration on the valuation of ecosystem services. MSc Thesis Environment and Resource Management VU University, Amsterdam, The Netherlands.

395 Brouwer R., Langford IH, Bateman IJ, Crowards TC, Turner RK, 1999. A metaanalysis of wetland contingent valuation studies. Regional Environmental Change 1, 47-57.

Brouwer R, Hofkes M, Linderhof V, 2008. General equilibrium modelling of the direct and indirect economic impacts of water quality improvements in the Netherlands at national and river 400 basin scale. Ecol Econ 66, 127-140.

Brouwer R, Bliem M, Flachner Z, Getzner M, Kerekes S, Milton S, Palarie T, Szerényi Z, Vadineanu A, Wagtendonk A., 2012. Ecosystem service valuation from floodplain restoration in the Danube River basin: an international choice experiment application. Internal paper IVM, VU 405 University, Amsterdam.

Bubeck P, De Moel H, 2010. Sensitivity analysis of flood damage calculations for the river Rhine. Study for DGWATER, final report, IVM Institute for Environmental Studies, VU University Amsterdam.

410

Cardinale BJ, Duffy JE, Gonzalez A, Hooper DU, Perrings C, Venai, P, Narwani A, Mace GM, Tilman D, Wardle DA, Kinzig AP, Daily GC, Loreau M, Grace JB, Larigauderie A, Srivastava DS, Naeem S, 2012. Biodiversity loss and its impact on humanity. Nature 486, 59-67

415 Carpenter SR, Mooney HA, Agard J, Capistrano D, DeFries RS, Díaz S, Dietz T, Duraiappah AK, Oteng-Yeboah A, Pereira HM, Perrings C, Reidl WV, Sarukhan J, Scholes RJ, Whyte A (2009) Science for managing ecosystem services: beyond the Millenium Ecosystem Assessment. Proc Nat Acad Sci 106:1305-1312

420 Coersen M, 2015. Ecosystem services valuation of degraded and non-degraded river segments of the Morrumsån river in Sweden. BSc thesis Earth Sciences and Economics, VU University Amsterdam

Davies CE, Moss D, Hill MO, 2004. EUNIS habitat classification revised 2004. Report to the

425 European Environment Agency and the European Topic Centre On Nature Protection And Biodiversity. Centre for Ecology and Hydrology, Dorchester, UK, 307 pp. See also: http://eunis.eea.eu.int/index.jsp 
DEFRA, 2007. An introductory guide to valuing ecosystem services. Department for Environment, 430 Food and Rural Affairs, London, UK, 65 pp.

De Groot RS, Alkemade R, Braat L, Hein L, Willemen L, 2010. Challenges in integrating the concept of ecosystem services and values in landscape planning, management and decision making. Ecol Complex 7, 260-272

435

De Klein JJM, Koelmans AA, 2011. Quantifying seasonal export and retention of nutrients in West European lowland rivers at catchment scale. Hydrol. Proc 25, 2102-2111.

Derwisch S, Schwendemann L, Olschewski R, Holscher D (2009) Estimation and economic 440 valuation of aboveground carbon storage of Tectona grandis plantations in Western Panama. New Forests 37:227-240

Dubgaard A,.Kallesøe M, Ladenburg J, Pedersen M, 2005. Cost-benefit analysis of the Skjern river restoration in Denmark. In: Brouwer, R. and D. Pearce (eds.): Cost benefit analysis and water 445 resource management. UK, Edward Elgar Publishing Cheltenham.

Fisher B, Turner RK, Morling P, 2009. Defining and classifying ecosystem services for decision making. Ecol Econ 68:643-653

450 Gielczewski M, 2003. The Narew river basin: a model for the sustainable management of agriculture, nature and water supply. $\mathrm{PhD}$ thesis Utrecht University, The Netherlands, $186 \mathrm{pp}$.

Gilvear DJ, Spray CJ, Casas-Mulet R, 2013. River rehabilitation for the delivery of multiple ecosystem services at the river network scale. J Env Manage 126, 30-43.

455

Gradzinski R, Baryla J, Doktor M, Gmur D, Gradzinski M, Kedzior A, Paszkowski M, Soja R, Zielinski T, Zurek S., 2003. Vegetation-controlled modern anastomosing system of the upper Narew River (NE Poland) and its sediments. Sed. Geol. 157, 253-276.

460 Hammer Ø, Harper DAT, Ryan, PD, 2001. Past: Paleontological Statistics Software package for education and data analysis. Paleont Electr 4, 4.

Haverkamp J, 2014. Assessing river restoration of two Austrian rivers, the Enns and the Drau, a comparative analysis of river restoration by valuing ecosystem services. MSc thesis Transnational

465 ecosystem-based Water Management, Radboud University Nijmegen, The Netherlands and University of Duisburg-Essen, Germany.

Hering D, Arovitta J, Baattrupp-Pedersen A, Brabec K, Buijze T, Ecke F, Friberg N, Gielczewski M, Januschke K, Kohler J, Kupilas B, Lorenz A, Muhar S, Paillex A; Poppe M, Schmidt T,

470 Schmutz S, Vermaat JE, Verdonschot P, Verdonschot R, submitted. Contrasting the roles of 
section length and instream habitat enhancement for river restoration success: a field study on 20 European restoration projects. J Appl Ecol.

Jähnig SC, Lorenz AW, Hering D, Antons C, Sundermann A, Jedicke E, Haase, P, 2011. River restoration success: a question of perception. Ecol Applic 21, 2007-2015

Kohut L, 2014. Evaluation of ecosystem services provided by restored and unrestored part of river Beczva, Czech Republic. Internal Report, Research Centre for Toxic Compounds in the Environment, Masaryk University, Brno, Czech Republic.

Lorenz AW, Feld CK, 2013. Upstream river morphology and riparian land use overrule local restoration effects on ecological status assessment. Hydrobiologia 704, 489-501

Martin-Lopez B, Gomez-Baggethun E, Garcia-Llorente, Montes C, 2014. Trade-offs across value485 domains in ecosystem services assessment. Ecol Indic 37, 220-228

Millennium Ecosystem Assessment (MEA), 2005. Ecosystems and human well-being, Summary for decision makers, Island Press, Washington D.C.

490 Morandi B, Piegay H, Lamouroux N, Vaudor L, 2014. How is success or failure in river restoration projects evaluated? Feedback from French restoration projects. J Env Manage 137, 178188.

Muhar S, Januschke K, Kail J, Poppe M, Hering D, Buijse, AD, this issue. Evaluating good495 practice cases for river restoration across Europe: context, methodological framework, selected results and recommendations. Hydrobiologia

Murray B, Jenkins A, Kramer R, Faulkner SP, 2009. Valuing ecosystem services from wetlands restoration in the Mississippi alluvial valley. Nicholas Institute reports 09-02, Duke University, 500 Durham, NC, USA, 43 pp.

Nabuurs GJ, Schelhaas M, 2002. Carbon profiles of typical forest types across Europe assessed with CO2FIX. Ecol Indic 1, 213-223.

505 Nelson E, Mendoza G, Regetz J, Polasky S, Tallis H, Cameron DR, Chan KM, Daily, GC, Goldstein J, Kareiva PM, Lonsdorf E, Naidoo R, Ricketts TH, Shaw MR, 2009. Modelling multiple ecosystem services, biodiversity conservation, commodity production, and tradeoffs at landscape scales. Front Ecol Environ. 7, 4-11

510 Olde Venterink H., Wiegman F., Van der Lee G.E.M., Vermaat J.E., 2003. Role of active floodplains for nutrient retention in the river Rhine. J Env Qual 32, 1430-1435 
Olde Venterink H, Vermaat JE, Pronk M, Wiegman F, Van der Lee GEM, Van den Hoorn MW, Higler LWG, Verhoeven, JTA, 2006. Importance of sedimentation and denitrification for plant

515 productivity and nutrient retention in various floodplain wetlands. Appl Veg Sci 9, 163-174

Palmer MA, Bernhardt ES, Allan JD, Lake PS, Alexander G, Brooks S, Carr J, Clayton S, Dahm CN, Follstad Shah J, Galat DL, Loss SG, Goodwin P, Hart DD, Hassett B, Jenkinson R, Kondolf GM, Lave R, Meyer JL, O'Donnell TK, Pagano L, Sudduth E, 2005. Standards for ecologically successful river restoration. J Appl Ecol 42, 208-217

Palmer M, Allan JD, Meyer J, Bernhardt ES, 2007. River restoration in the twenty-first century: data and experiential knowledge to inform future efforts. Restor Ecol 15, 472-481.

525 Pedersen ML, Friberg N, Skriver J, Baattrup-Pedersen A, Larsen SE, 2007. Restoration of Skjern river and its valley - Short-term effects on river habitats, macrophytes and macroinvertebrates. Ecol Engin 30, 145-156.

Plug MC, 2014. Uncovering the pitfalls and quantifying the merits of river restoration: a case study 530 on the Finnish Vääräjoki. MSc Thesis Earth Sciences and Economics, VU University Amsterdam, The Netherlands.

Skøien JO, Blöschl G, Western AW, 2003. Characteristic space scales and timescales in hydrology. Water Resources Research 39, 1304.

535

Střeleček F, Lososová J, Zdeněk R, 2011. Farmland rent in the European Union. Acta univ. agric. et silvic. Mendel. Brun. 59, 309-318.

Turner RK, Van den Bergh JCJM, Soderqvist T, Barendregt A, Van der Straaten J, Maltby E, Van

540 Ierland EC, 2000. Ecological-economic analysis of wetlands: scientific integration for management and policy. Ecol Econ 35, 7-23.

Tylec L, 2013. An assessment of the societal benefits of the Narew river restoration versus the restoration costs using the ecosystem services approach. MSc thesis Civil and Environmental

545 Engineering, Warsaw University of Life Sciences, Warsaw, Poland.

Underwood AJ, 1996. Experiments in ecology: their logical design and interpretation using analysis of variance. Cambridge University Press

550 Van Teeffelen A, Miller L, Van Minnen J, Vermaat JE, Cabeza M, 2014. How climate proof is the European Union's biodiversity policy? Reg Env Change doi: 10.1007/s10113-014-0647-3

Vermaat JE, Ansink E, Catalinas Perez M, Wagtendonk A, Brouwer R, 2013. Valuing the ecosystem services provided by European river corridors - an analytical framework. Report D2.3

of the FP7 project REFORM. http://www.reformrivers.eu/deliverables/d2-3 
Von Arnold K, Nilsson M, Hanell B, Weslien P, Klemendtsson L, 2005. Fluxes of $\mathrm{CO}_{2}, \mathrm{CH}_{4}$ and $\mathrm{N}_{2} 0$ from drained organic soils in deciduous forests. Soil Biol Biochem 37, 1059-1071.

Wallace KJ, 2007. Classification of ecosystem services: problems and solutions. Biol Conserv 139, $560 \quad 235-246$

Watson R, Albon S (eds), 2011. The UK National Ecosystem Assessment: synthesis of the key findings. UNEP-WCMC, Cambridge, UK.

565 Weber, JL, 2011. An experimental framework for ecosystem capital accounting in Europe. EEQA technical Report 13/2011. EEA Copenhagen, 43 pp.

Westmann WE, 1977. How much are Nature's services worth? Measuring the social benefits of ecosystem functioning is both controversial and illuminating. Science 197, 960-964

570

Zedler JB, Kercher S, 2005. Wetland resources: status, trends, ecosystem services and restorability. Ann Rev Env Resourc 30, 39-74 


\section{Figures and tables}

a.

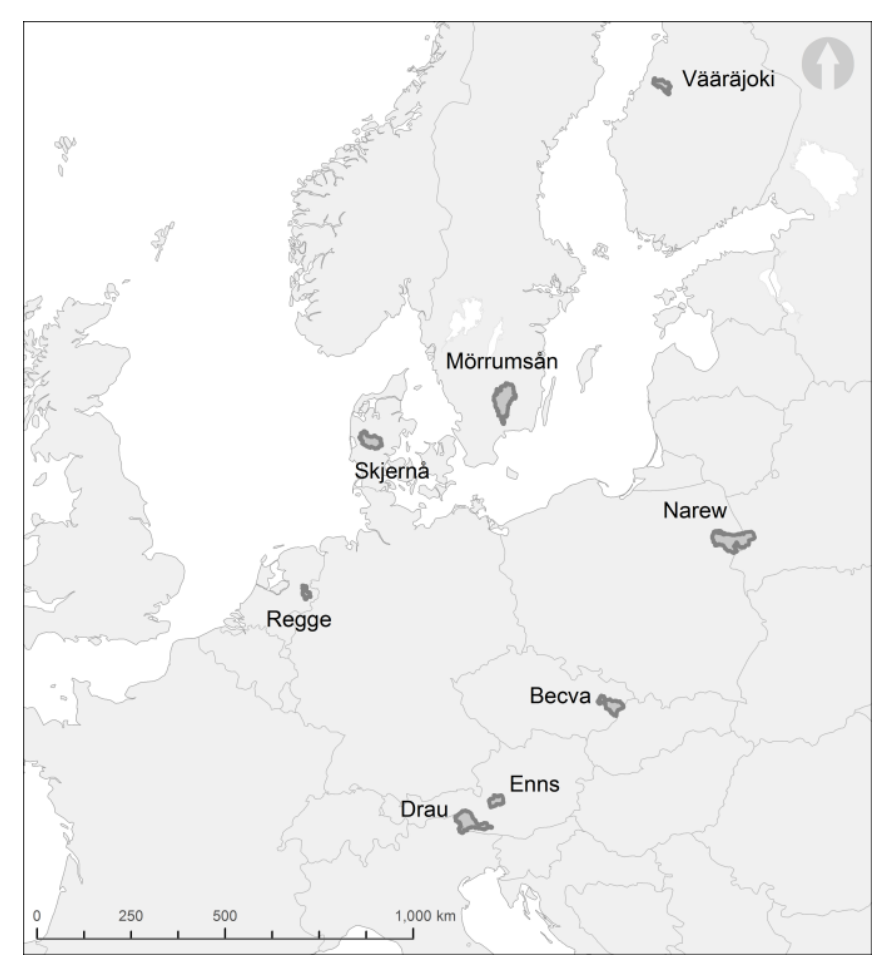

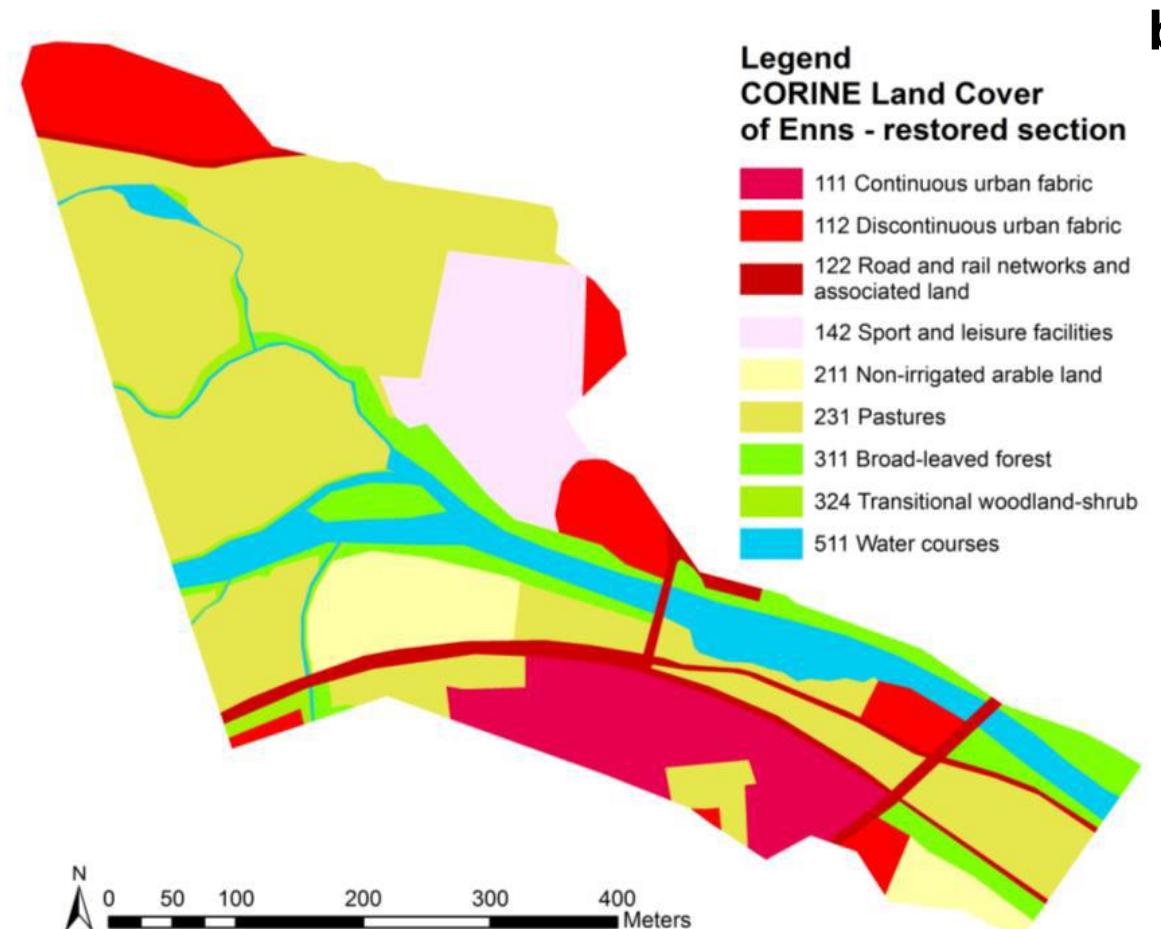

Legend

CORINE Land Cover

Ens - restored section

Meters

b.

580 Figure 1. (a) Location of the study sites across Europe. Indicated are the catchments above the lowest point of the restored or control reach, whichever was further downstream. (b) CORINE habitat map of one of the studied reaches, here the restored reach of the Enns in Austria (from Haverkamp, 2014). The legend provides the CORINE three-level classification used (see also Vermaat et al., 2013). 


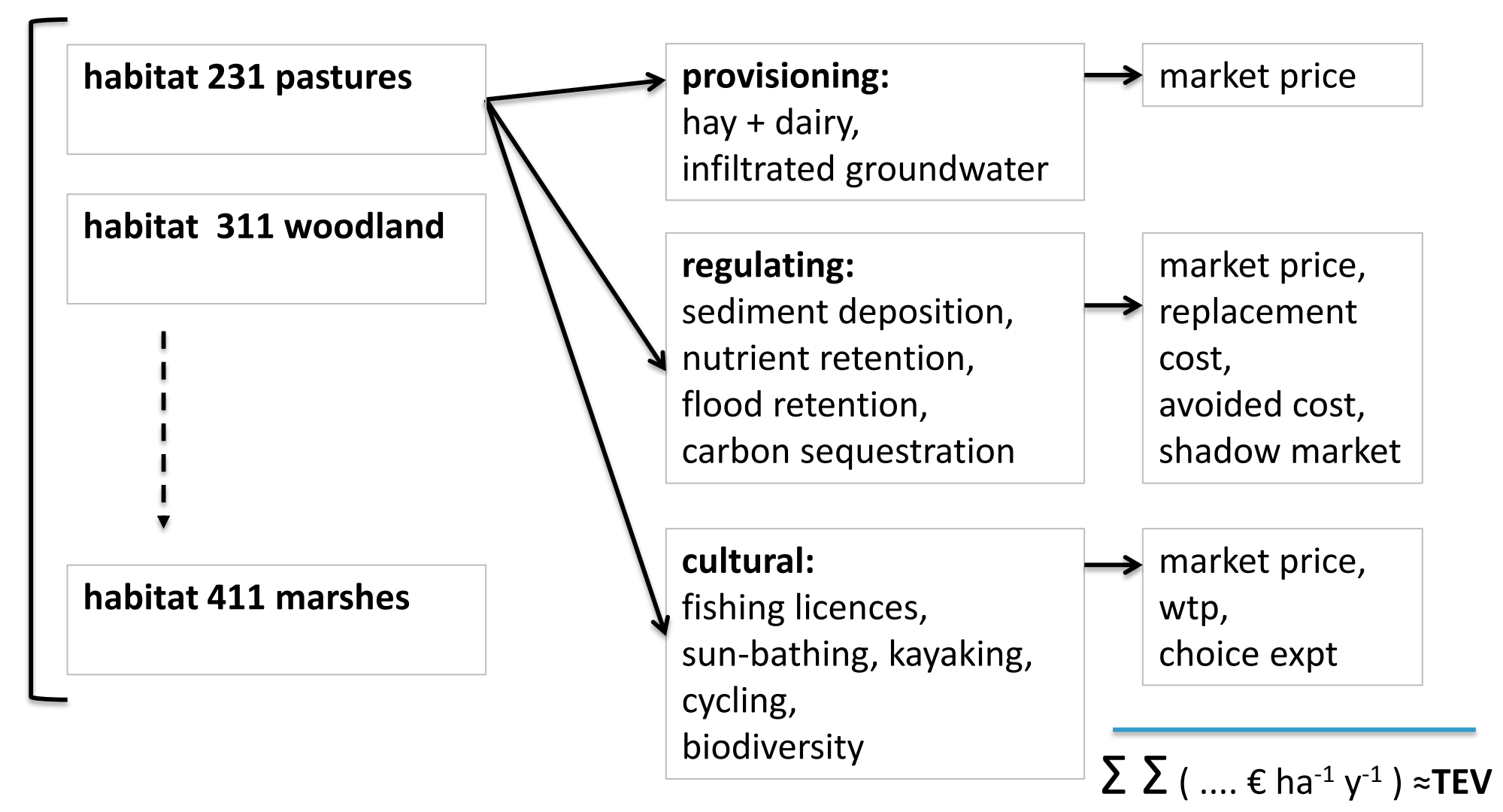

Figure 2. Flow scheme of the valuation procedure followed for habitats within reaches. Habitat coding is according to CORINE, but only three habitats are displayed for illustrative purpose. Different services and economic methodology are 
a.

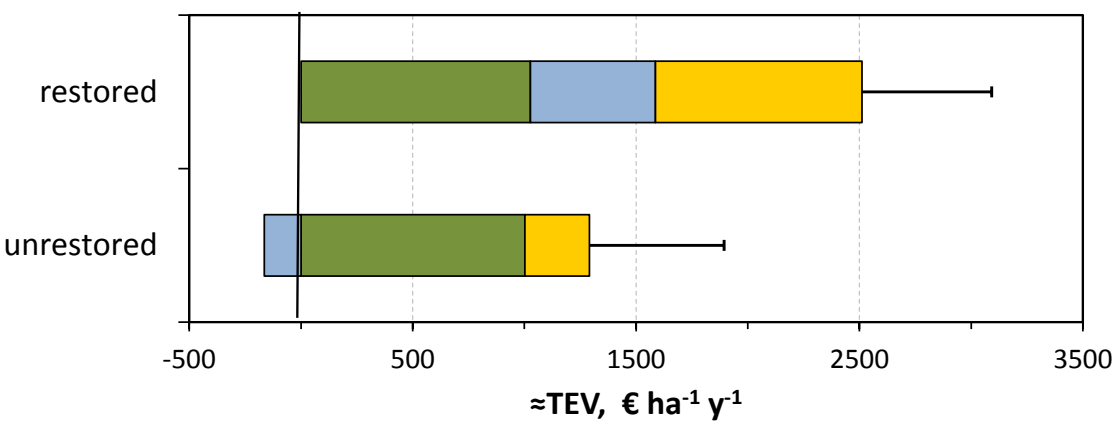

b.

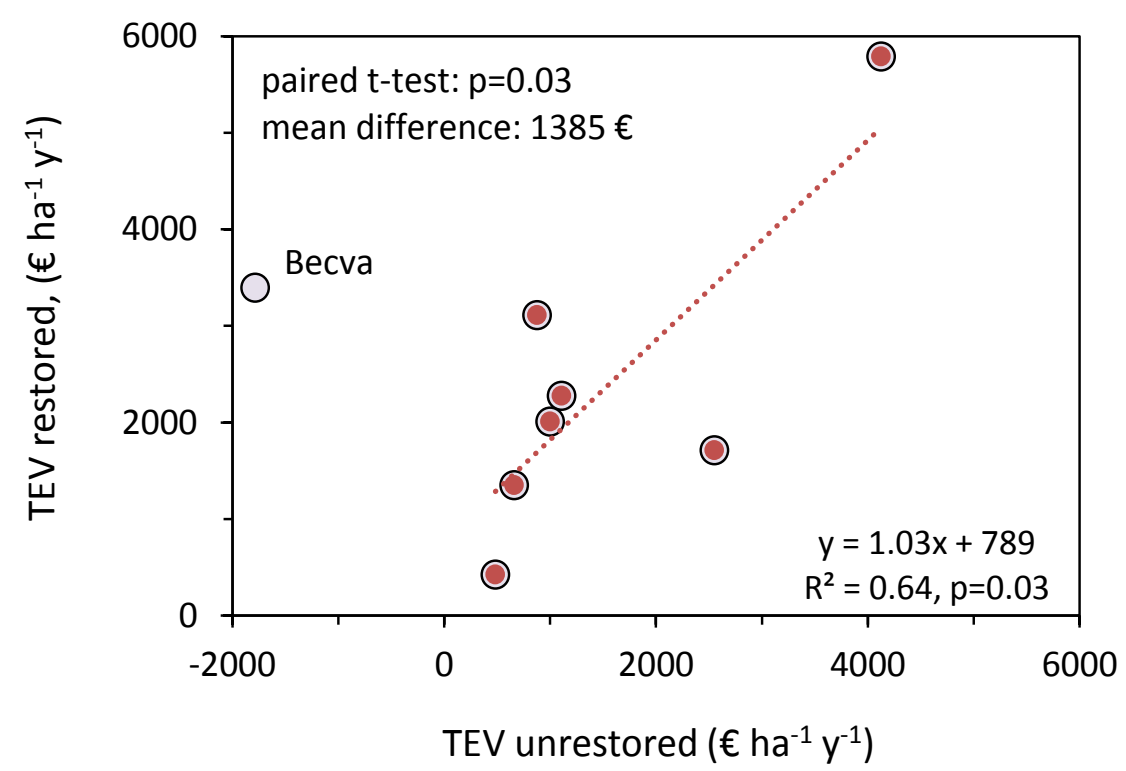

$\square$ provisioning

$\square$ regulating

$\square$ cultural (+ total SE)

Figure 3. Overall difference in estimated service delivery between restored and unrestored reaches. (a) Overall stacked means plus 1 standard error of total services (similar bar charts for individual rivers are in the supplementary material S1 (b) Scatter plot of restored versus unrestored total services. If the Becva is excluded, the regression is significant. Similar separate regressions for all 8 pairs were made for provisioning services (not significant), regulating services $(p<0.05$, but not significant without the Becva), and cultural services (slope 1.5, $\mathrm{p}<0.01$ ). 

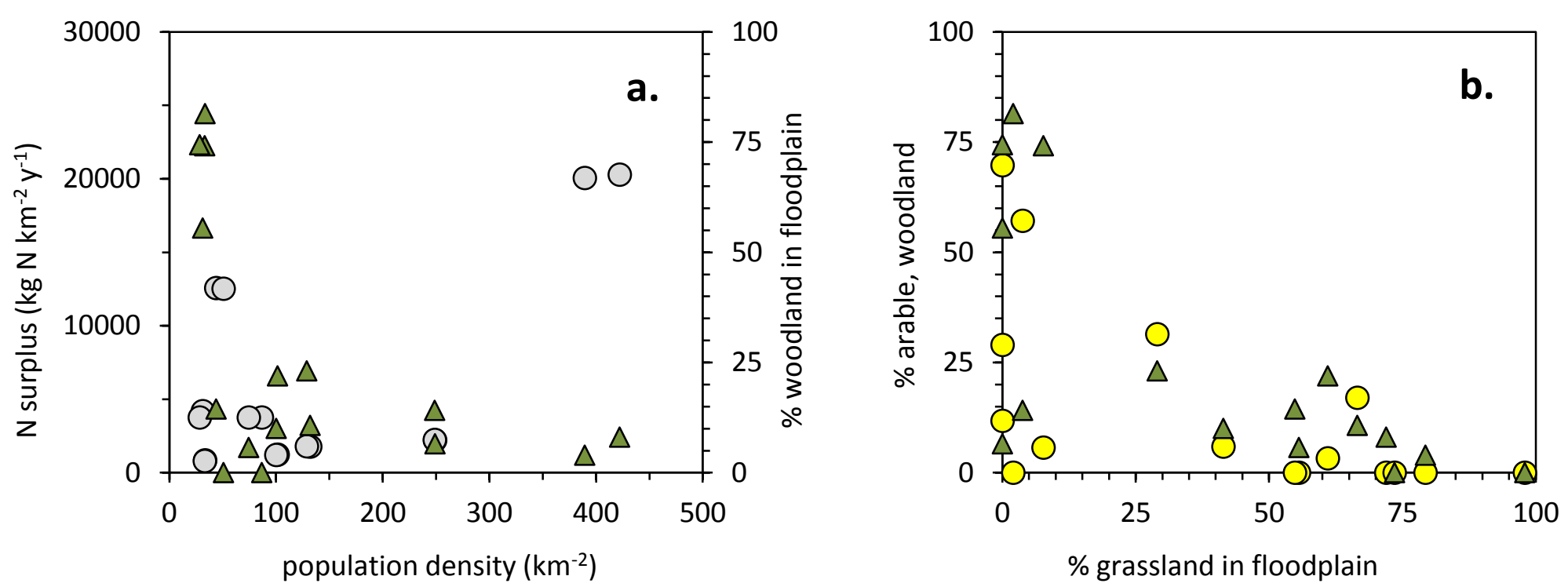

Figure 4. (a) Variability in catchment human population density versus catchment Nitrogen surplus of agriculture (circles) and percentage woodland in the floodplain (triangles); (b) percentage woodland (triangles) and arable land (circles) versus grassland in the studied floodplains. 

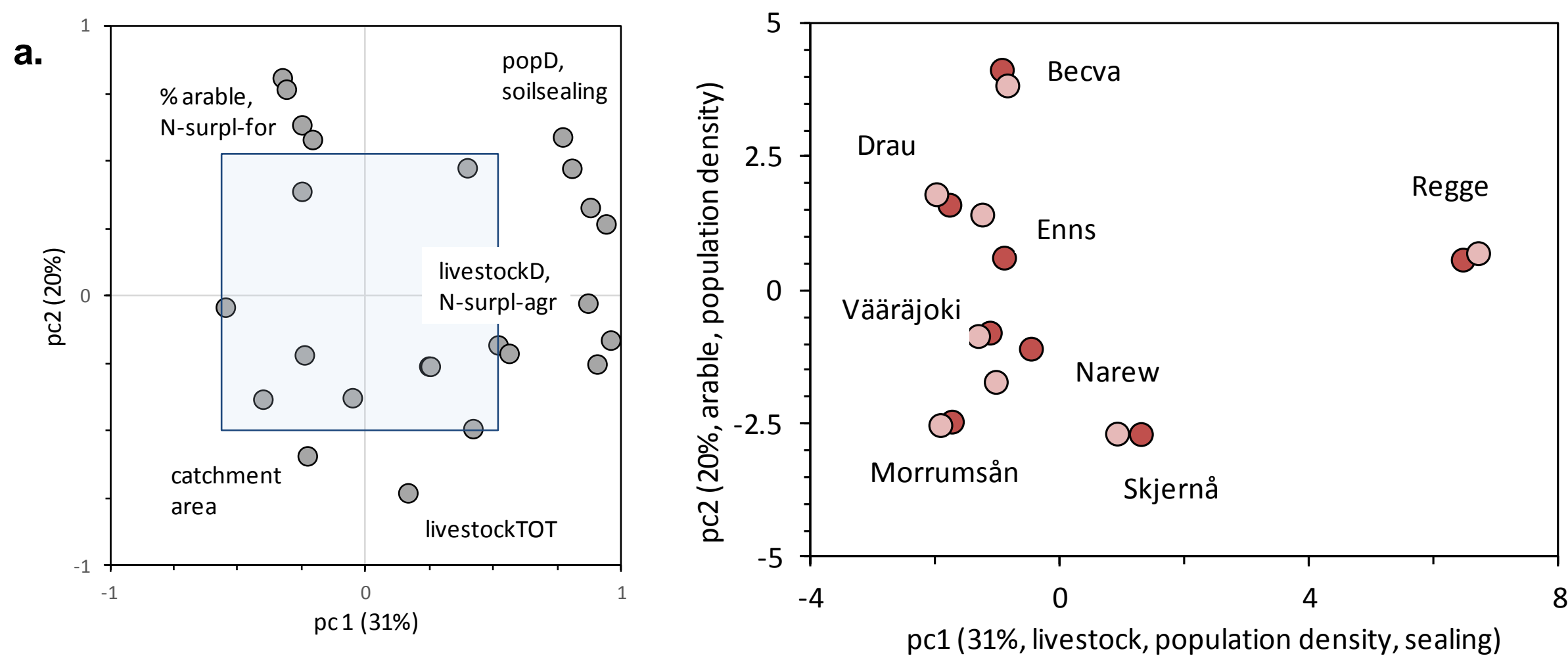

b.

Figure 5. Principal components analysis of 23 catchment and river corridor variables. (a) Correlations of the original variables versus the first two principal components are plotted. Four principal components explained more than $10 \%$ of the variance, together $82 \%$. The transparent blue square depicts the area where $r<0.5$, corresponding to $p>0.05$ for pairwise linear regressions, within this area we consider the variables to be not correlated with either principal component. Variable labels: $\%$ arable $=$ percentage arable land in the floodplain, $\mathrm{N}$-surpl-for = Nitrogen surplus in the forested part of the catchment, popD = human population density in the catchment, soilsealing = the proportion of the catchment area paved, livestockD is cattle density, N-surpl-agr = Nitrogen surplus in

615 the agricultural part of the catchment, livestockTOT = total livestock number in the catchment, catchment area = the area upstream of the reach. Note that we used both mean and standard deviation of a catchment variable, the latter to grasp variability within a catchment. These however were almost always very closely correlated. (b) Plot of the 8 pairs of restored and unrestored reaches versus the first two principal components (see figure 4), darker symbol: unrestored, lighter symbol: restored. 


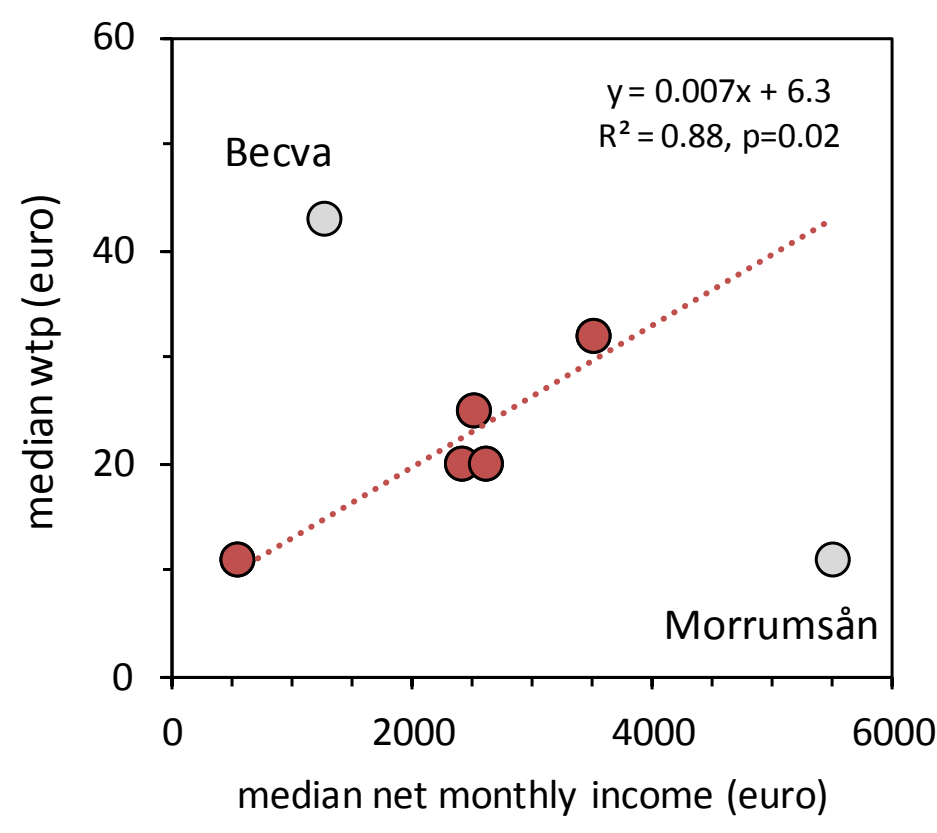

Fig. 6. Median willingness-to-pay per household for river restoration from the seven field surveys versus median reported net monthly income. Displayed regression fit without the data from Becva and Morrumsån. 
Table 1. Characterisation of the studied restoration sites along 9 European rivers. Underlined references are our own local case studies a.o. containing the wtp-surveys. The Regge is locally known as Beneden Regge.

\begin{tabular}{|c|c|c|c|c|c|c|c|c|}
\hline River & $\begin{array}{l}\text { Regge (The } \\
\text { Netherlands) }\end{array}$ & $\begin{array}{l}\text { Skjernå } \\
\text { (Denmark) }\end{array}$ & $\begin{array}{l}\text { Mörrumsån } \\
\text { (Sweden) }\end{array}$ & $\begin{array}{l}\text { Vääräjoki } \\
\text { (Finland) }\end{array}$ & Narew (Poland) & $\begin{array}{l}\text { Becva (Czech } \\
\text { Republic) }\end{array}$ & $\begin{array}{l}\text { Enns } \\
\text { (Austria) }\end{array}$ & Drau (Austria) \\
\hline $\begin{array}{l}\text { Coordinates }\left({ }^{\circ} . N \text {, }\right. \\
\text { E) }\end{array}$ & $52.30,6.23$ & $55.54,8.23$ & $56.18,14.43$ & $63.11,24.02$ & $53.08,22.52$ & $49.27,17.28$ & $47.25,13.49$ & $46.45,13.19$ \\
\hline $\begin{array}{l}\text { Mean annual } \\
\text { discharge }\left(\mathrm{m}^{3} \mathrm{~s}^{-1}\right)\end{array}$ & 11 & 35 & 25 & 10 & 17 & 18 & 22 & 63 \\
\hline $\begin{array}{l}\text { Floodplain slope (m } \\
\mathrm{km}^{-1} \text {, linear, } \\
\text { upstream of reach, } \\
\mathrm{r}^{2} \text { indicates } \\
\text { goodness of linear } \\
\text { fit) }\end{array}$ & $\begin{array}{l}-0.207 \\
\left(r^{2}=0.15\right)\end{array}$ & $\begin{array}{l}-0.604 \\
\left(r^{2}=0.78\right)\end{array}$ & $\begin{array}{l}-0.872 \\
\left(r^{2}=0.65\right)\end{array}$ & $\begin{array}{l}-0.376 \\
\left(r^{2}=0.20\right)\end{array}$ & $-0.255\left(r^{2}=0.56\right)$ & $-1.565\left(r^{2}=0.58\right)$ & $\begin{array}{l}-2.882 \\
\left(r^{2}=0.48\right)\end{array}$ & $\begin{array}{l}-5.392 \\
\left(r^{2}=0.79\right)\end{array}$ \\
\hline $\begin{array}{l}\text { surrounding } \\
\text { landscape }\end{array}$ & $\begin{array}{l}\text { Mainly flat, } \\
\text { sandy } \\
\text { dairyland } \\
\text { with glacial } \\
\text { moraine } \\
\text { ridges }\end{array}$ & $\begin{array}{l}\text { Extensive } \\
\text { sandy flat } \\
\text { plateaus } \\
\text { dissected by } \\
\text { broad } \\
\text { periglacial } \\
\text { tunnel } \\
\text { valleys, } \\
\text { mainly under } \\
\text { agriculture } \\
\end{array}$ & $\begin{array}{l}\text { Forested } \\
\text { bedrock hills } \\
\text { with } \\
\text { interspersed } \\
\text { bogs and } \\
\text { river valley } \\
\text { under } \\
\text { agriculture }\end{array}$ & $\begin{array}{l}\text { Forested } \\
\text { bedrock hills } \\
\text { with } \\
\text { interspersed } \\
\text { bogs and river } \\
\text { valley under } \\
\text { agriculture }\end{array}$ & $\begin{array}{l}\text { Gently rolling } \\
\text { plateaus under } \\
\text { agriculture of } \\
\text { variable } \\
\text { underlying } \\
\text { geology } \\
\text { interspersed by } \\
\text { marshy, wide } \\
\text { periglacial river } \\
\text { valleys. }\end{array}$ & $\begin{array}{l}\text { Floodplains and } \\
\text { foothills largely } \\
\text { agricultural, } \\
\text { upslope } \\
\text { Carpathian } \\
\text { mountains under } \\
\text { forest }\end{array}$ & $\begin{array}{l}\text { Comparative } \\
\text { ly broad } \\
\text { alpine valley } \\
\text { with } \\
\text { agriculture at } \\
\text { the bottom } \\
\text { and forest } \\
\text { and } \\
\text { rangelands } \\
\text { higher up. }\end{array}$ & $\begin{array}{l}\text { Comparatively } \\
\text { broad valley } \\
\text { with } \\
\text { agriculture at } \\
\text { the bottom and } \\
\text { forest and } \\
\text { rangelands } \\
\text { higher up. }\end{array}$ \\
\hline $\begin{array}{l}\text { Restoration } \\
\text { measures }\end{array}$ & $\begin{array}{l}\text { Re- } \\
\text { meandered, } \\
\text { re- } \\
\text { landscaped } \\
\text { and lowered }\end{array}$ & $\begin{array}{l}\text { Re- } \\
\text { meandered, } \\
\text { re-connected } \\
\text { old arms, } \\
\text { reduced } \\
\text { depth in }\end{array}$ & $\begin{array}{l}\text { Enhanced } \\
\text { minimal flow } \\
\text { with } \\
\text { hydraulic } \\
\text { measures, } \\
\text { added gravel }\end{array}$ & $\begin{array}{l}\text { Returned large } \\
\text { boulders into } \\
\text { the river bed, } \\
\text { reconstructed } \\
\text { gravel beds for }\end{array}$ & $\begin{array}{l}\text { Floodplain re- } \\
\text { wetting with a } \\
\text { downstream weir, } \\
\text { reconnect side } \\
\text { arms, }\end{array}$ & $\begin{array}{l}\text { Allow natural } \\
\text { channel } \\
\text { development } \\
\text { and migration } \\
\text { after } \\
\text { unprecedented }\end{array}$ & $\begin{array}{l}\text { Stream bed } \\
\text { widened and } \\
\text { side arm re- } \\
\text { opened, }\end{array}$ & $\begin{array}{l}\text { Stream bed } \\
\text { widened and } \\
\text { side arm re- } \\
\text { opened, }\end{array}$ \\
\hline
\end{tabular}




\begin{tabular}{|c|c|c|c|c|c|c|c|c|}
\hline & $\begin{array}{l}\text { the } \\
\text { floodplain }\end{array}$ & $\begin{array}{l}\text { main } \\
\text { channel, re- } \\
\text { landscaped } \\
\text { and lowered } \\
\text { the } \\
\text { floodplain }\end{array}$ & $\begin{array}{l}\text { beds, } \\
\text { facilitated } \\
\text { upstream } \\
\text { fish } \\
\text { migration }\end{array}$ & $\begin{array}{l}\text { spawning } \\
\text { salmonids }\end{array}$ & & $\begin{array}{l}\text { flood event in } \\
\text { summer } 1997\end{array}$ & & \\
\hline $\begin{array}{l}\text { Length restored - } \\
\text { unrestored (km } \\
\text { along main stream } \\
\text { axis) }\end{array}$ & $1.1-0.7$ & $\begin{array}{l}2.6 \text { (in a } \\
\text { much larger } \\
\text { project) }-1.5\end{array}$ & $3.1-2.4$ & $16-30$ & $4-5$ & $\begin{array}{l}7 \text { (part of a } \\
\text { much larger } \\
\text { project) - } 7\end{array}$ & $0.7-0.8$ & $2-1$ \\
\hline $\begin{array}{l}\text { Number of } \\
\text { interviewed people, } \\
\% \text { visitors, \% willing } \\
\text { to respond }\end{array}$ & $\begin{array}{l}100,30 \% \\
\text { not recorded }\end{array}$ & $\begin{array}{l}\text { None } \\
\text { (benefit } \\
\text { transfer) }\end{array}$ & $\begin{array}{l}47,23 \% \\
20 \%\end{array}$ & $\begin{array}{l}67,14 \% \text {, not } \\
\text { recorded }\end{array}$ & $100,14 \%, 30 \%$ & $27,44 \%, 30 \%$ & $\begin{array}{l}71,10 \% \\
50 \%\end{array}$ & $\begin{array}{l}112,20 \%, \\
51 \%\end{array}$ \\
\hline $\begin{array}{l}\text { Estimated resident } \\
\text { population } \\
\text { represented by the } \\
\text { interviewed sample }\end{array}$ & $8400^{*}$ & - & 31000 & 6010 & 130000 & 74000 & 3351 & 5446 \\
\hline $\begin{array}{l}\text { Choice experiment } \\
\text { design }{ }^{\star \star} \text {, attributes } \\
\text { and associated } \\
\text { range of additional } \\
\text { annual water tax } \\
\text { payment per } \\
\text { household }\end{array}$ & $\begin{array}{l}\text { Accessibility } \\
\text { ( } 3 \text { levels), } \\
\text { flood risk (1 } \\
\text { in 10, 25, } \\
100 \text { y), water } \\
\text { quality (3); } 0- \\
25 €\end{array}$ & - & $\begin{array}{l}\text { Accessibility } \\
(3), \\
\text { hydropower } \\
(3), \\
\text { presence } \\
\text { migrant } \\
\text { salmonids } \\
(3) ; 0-20 €\end{array}$ & $\begin{array}{l}\text { Landscape } \\
\text { aesthetics (3), } \\
\text { length restored } \\
\text { (3), ecological } \\
\text { status (3), 0- } \\
70 €\end{array}$ & $\begin{array}{l}\text { Landscape quality } \\
\text { (3), biodiversity } \\
\text { (3), water quality } \\
\text { (3); 0-60 PLN }\end{array}$ & $\begin{array}{l}\text { Landscape } \\
\text { aesthetics (3), } \\
\text { flood risk (3), } \\
\text { biodiversity (3); } \\
\text { 0-150 CZK }\end{array}$ & $\begin{array}{l}\text { Accessibility } \\
\text { (3), flood risk } \\
\text { (3), } \\
\text { ecological } \\
\text { quality (3), } \\
\text { length } \\
\text { restored (3); } \\
0-30 €\end{array}$ & As Enns \\
\hline Period interviews & April 2013 & - & May 2014 & May 2013 & August 2013 & September 2014 & $\begin{array}{l}\text { April-May } \\
2014\end{array}$ & $\begin{array}{l}\text { May-June } \\
2014\end{array}$ \\
\hline Main source & $\frac{\text { Brockhoff }}{(2013)}$ & $\begin{array}{l}\text { Dubgaard et } \\
\text { al. (2005), }\end{array}$ & $\frac{\text { Coerssen }}{(2015)}$ & Plug (2014) & $\begin{array}{l}\text { Grazinski et al. } \\
\text { (2003), Gielcewski } \\
\text { (2003), Banaszuk }\end{array}$ & Kohut (2014) & $\frac{\text { Haverkamp }}{(2014)}$ & $\frac{\text { Haverkamp }}{(2014)}$ \\
\hline
\end{tabular}




\begin{tabular}{|l|l|l|l|l|l|l|l|}
\hline & $\begin{array}{l}\text { Pedersen et } \\
\text { al. (2007) }\end{array}$ & & & $\begin{array}{l}\text { et al (2005), } \\
\text { Banaszuk and } \\
\text { Kamocki (2008), } \\
\text { Tylec (2013) }\end{array}$ & \\
& & & & & \\
\hline
\end{tabular}

Notes

* Estimated from the percentage willing to be interviewed, the percentage residents in the sample and the most recent reported population of the riparian municipality. Brockhoff (2013) estimated the existence value of the biodiversity component of cultural service from the wtp and the total visits of 8400 during the tourist season of 7 months; he did not estimate the percentage of non-respondents, and adjacent villages have a population of 14000 , which is not so high that we considered it necessary to include an extra value due to non-visiting residents.

** Each choice experiment compared two alternatives with the status quo in 6 or 8 choice cards. Card combination allocation was either optimized or fully random (Vääräjoki, Narew). Water quality and ecological status were chosen to correspond with status levels of the European Water Framework Directive. 
Table 2. Approaches to estimate the different specific ecosystem services. Different local market price estimates are in the case study reports (see row 'main source' in table 1 for references)

\begin{tabular}{|c|c|c|}
\hline Service category & Quantification in biophysical units & Monetary valuation \\
\hline \multirow[t]{8}{*}{ provisioning } & Hay, grass, fodder (crops $\mathrm{y}^{-1}$ ) & $\begin{array}{l}\text { Local market price (following Dubgaard et al., } \\
2005 \text { and Brander et al., 2006) }\end{array}$ \\
\hline & Dairy, meat (production $\mathrm{y}^{-1}$ ) & Local market price \\
\hline & Arable crops, vegetables, fruit (crops $\mathrm{y}^{-1}$ ) & Local market price \\
\hline & $\begin{array}{l}\text { Wood harvested for construction, paper or fuel (production } \mathrm{y}^{-1} \text {, artisanal } \\
\text { firewood collection not included) }\end{array}$ & Local market price \\
\hline & Reed crop for thatching (crops $\mathrm{y}^{-1}$, only Skjernå) & Local market price \\
\hline & $\begin{array}{l}\text { Drinking water production after bank infiltration or deep infiltration to } \\
\text { aquifer }\left(\mathrm{m}^{3} \mathrm{y}^{-1}\right)\end{array}$ & Local market price \\
\hline & $\begin{array}{l}\text { Hydropower is generated along the Austrian Enns and Drau and in the } \\
\text { Swedish Morrumsån. Hydropower provision was not affected by the } \\
\text { restoration measures carried out in Austria and the estimated reduction } \\
\text { due to restoration in the Morrumsån was hard to verify. A difference in } \\
\text { service delivery therefore has not been estimated. }\end{array}$ & Not valued \\
\hline & $\begin{array}{l}\text { Commercial fish catch: not valued, only recreative fishing occurs in the } \\
\text { studied rivers, which is valued as cultural service }\end{array}$ & Not valued \\
\hline \multirow[t]{2}{*}{ regulating } & $\begin{array}{l}\text { Avoided in-reach and downstream flood damage: area flooded times } \\
\text { crops lost, reduced forest tree growth, property damage. }\end{array}$ & $\begin{array}{l}\text { Local market value or damage scanner } \\
\text { (Bubeck \& De Moel, 2010), using } \\
\text { conservative median damage per CORINE } \\
\text { land use category and discounting for the } \\
\text { flood interval available in the local flood } \\
\text { statistics. }\end{array}$ \\
\hline & $\begin{array}{l}\text { Sediment retention may contribute to downstream sediment fill-up, } \\
\text { riverbed silting and hydropower impediment. It has not been valued } \\
\text { separately since data availability was insufficient. }\end{array}$ & Not valued \\
\hline
\end{tabular}


Nutrient retention. Either phosphorus or nitrogen mass removed during flooding $\left(\mathrm{kg} \mathrm{ha}^{-1} \mathrm{y}^{-1}\right)$, to prevent double counting. Retention estimated from concentrations, flow volumes, flood duration, area flooded and habitat specific retention rates (Olde-Venterink et al., 2003, 2006), and a generic in-stream retention estimate from De Klein \& Koelmans (2011).

Carbon sequestration in forest wood and marshland peat: annual accumulation from conservative estimates of aboveground accumulation: ( 0.1 and 2 ton $\mathrm{C} \mathrm{ha}^{-1} \mathrm{y}^{-1}$ for wetlands and woodlands, respectively, Nabuurs and Schelhaas, 2002; Von Arnold et al., 2005)

Reduced pumping costs to drain floodplain for agricultural exploitation (Skjernå only)

\section{Cultural services Hunting, fishing}

Kayaking, rafting

Sun-bathing, cycling

Existence value, increased water quality, scenic beauty and biodiversity
Local fertilizer market price or annualized marginal cost of the least expensive eutrophication abatement measure (Skjernå)

Low-end shadow market carbon credit estimate (19€ ton ${ }^{-1}$, from Derwisch et al. 2009).

Directly taken from Dubgaard et al. (2005)

Local numbers of licences issued times licence fee

Local rental fees

Not valued, considered free

From different local wtp-questionnaires and choice experiments (see table 1 for key references, design summary and response rates) 
Table 3. Relation between ecosystem service value estimates and catchment and river corridor characteristics. The latter are represented by the first four principal components to accommodate for considerable covariance among the 23 variables (Fig. 4). Presented are the levels of significance (p) for each of the four principal components as covariates and restoration (yes, no) as fixed factor in four separate GLM-ANOVAs with type III sums of squares. Also given is the explained variance (adjusted $r^{2}$ ) of each of the full models. All $p<0.1$ are printed bold.

\begin{tabular}{lcccc}
\hline factor & provisioning & regulating & cultural & total \\
\hline pc 1 & 0.157 & 0.219 & $\mathbf{0 . 0 0 0}$ & $\mathbf{0 . 0 0 2}$ \\
pc 2 & 0.685 & 0.761 & 0.479 & 0.727 \\
pc 3 & 0.720 & 0.923 & 0.989 & 0.833 \\
pc 4 & 0.123 & 0.641 & 0.835 & 0.131 \\
restoration & & & \\
$\begin{array}{l}\text { (yes/no) } \\
\text { adjusted r }\end{array}$ & 0.871 & 0.074 & 0.006 & $\mathbf{0 . 0 2 7}$ \\
\hline
\end{tabular}




\section{Supplementary material S1. Table 1. GIS variables and the sources these have been extracted from.}

680

\begin{tabular}{|c|c|c|c|c|c|c|}
\hline variable & \begin{tabular}{|l|} 
Name \\
dataset
\end{tabular} & Units & Currency & Resolution & $\begin{array}{l}\begin{array}{l}\text { Reference } \\
\text { system }\end{array} \\
\end{array}$ & Data source \\
\hline $\begin{array}{l}\text { Nitrogen } \\
\text { surplus }\end{array}$ & $\begin{array}{l}\mathrm{N} \text {-surplus } \\
\text { for } \\
\text { agricultural } \\
\text { soils and } \\
\text { forests / } \\
\text { rough } \\
\text { grazing } \\
\end{array}$ & $\mathrm{kgN} / \mathrm{km}^{2} / \mathrm{yr}$ & 2002 & $1 \mathrm{~km}$ grids & $\begin{array}{l}\text { ETRS } 1989 \\
\text { LAEA }\end{array}$ & ftp://mars.jrc.ec.europa.eu/Afoludata/Public/DS237 \\
\hline $\begin{array}{l}\text { Livestock } \\
\text { density }\end{array}$ & \begin{tabular}{|l|} 
Livestock \\
density - \\
livestock \\
units per \\
ha by \\
NUTS 2, \\
2007 \\
\end{tabular} & LSU/ha & 2007 & NUTS2 ${ }^{*}$ & n.a. & $\begin{array}{l}\text { http://epp.eurostat.ec.europa.eu/statistics explained/images/3/39/Agriculture and environment 2011.x } \\
\text { http://epp.eurostat.ec.europa.eu/tgm/refreshTableAction.do?tab=table\&pcode=tgs00045\&language=en }\end{array}$ \\
\hline $\begin{array}{l}\text { Population } \\
\text { density }\end{array}$ & \begin{tabular}{|l|} 
GEOSTAT \\
population \\
density \\
grid 2006 \\
per km2 \\
\end{tabular} & persons $/ \mathrm{km} 2$ & $\begin{array}{l}2006 \\
\text { (LAU } \\
\text { data) }\end{array}$ & $\begin{array}{l}1000 \\
\text { meter }\end{array}$ & $\begin{array}{l}\text { ETRS } 1989 \\
\text { LAEA }\end{array}$ & http://epp.eurostat.ec.europa.eu/portal/page/portal/gisco Geographical information maps/popups/refer \\
\hline GDP & $\begin{array}{l}\text { GDP } 2011 \\
\text { Eurostat in } \\
\text { PPS on } \\
\text { NUTS } 3 \\
\text { level (\% of } \\
\text { EU28 } \\
\text { average) } \\
\end{array}$ & $\begin{array}{l}\% \text { of EU-28 } \\
\text { average, } \\
\text { EU-28 }=100\end{array}$ & 2011 & NUTS3 & n.a. & http://epp.eurostat.ec.europa.eu/statistics explained/images/3/3c/Economy RYB2014.xlsX \\
\hline $\begin{array}{l}\text { Impervious } \\
\text { area }\end{array}$ & \begin{tabular}{|l|} 
EEA Fast \\
Track \\
Service \\
Precursor \\
on Land \\
Monitoring \\
- Degree \\
of soil \\
sealing \\
\end{tabular} & $\%$ sealing/ha & 2006 & $\begin{array}{l}100 \times 100 \\
\mathrm{~m} \text { grids }\end{array}$ & EPSG:3035 & p://www.eea.europa.eu/data-and-maps/data/eea-fast-track-service-precursor-on-land-monitoring-d \\
\hline $\begin{array}{l}\text { Discharge } \\
\text { points }\end{array}$ & $\begin{array}{l}\text { Waterbase } \\
\text { - UWWTD: } \\
\text { Urban } \\
\text { Waste } \\
\text { Water }\end{array}$ & $\begin{array}{l}\text { n.a. } \\
\text { (discharge } \\
\text { points) }\end{array}$ & $\begin{array}{r}2007- \\
2011\end{array}$ & $\begin{array}{l}\text { n.a. (point } \\
\text { scale) }\end{array}$ & $\begin{array}{l}\text { Geographic, } \\
\text { WGS84 }\end{array}$ & w.eea.europa.eu/data-and-maps/data/waterbase-uwwtd-urban-waste-water-treatment-directi \\
\hline
\end{tabular}


Treatment

Directive 
Supplementary Material S1 table 2. Geographic catchment and reach corridor data used in the multivariate analysis.

\begin{tabular}{|c|c|}
\hline label & explanation \\
\hline \multicolumn{2}{|l|}{ catchment } \\
\hline lengthrestoredkm & $\begin{array}{l}\text { length of the restored reach that was used in the assessment of } \\
\text { ecosystem services. It is possible that these are only part of a larger } \\
\text { restoration project, fx in Skjernå, Becva and Regge }\end{array}$ \\
\hline typeofrestoration & $\begin{array}{l}\text { this is a brief text used to turn a qualitative impression of the intensity } \\
\text { and extent of the restoration project into a simple number, which } \\
\text { follows in the next column }\end{array}$ \\
\hline typeofrestorationnumber & code $1,2,3$ in increasing severity \\
\hline domesticsewageeffluents & $\begin{array}{l}\text { the number of waste water discharge points into the river in the } \\
\text { catchment upstream }\end{array}$ \\
\hline PPS2011 & $\begin{array}{l}\text { a purchasing parity gdp per capita used to estimate the percentage in } \\
\text { the next variable }\end{array}$ \\
\hline gdppercentageeu & percentage gdp per capita of grand overall mean EU28 \\
\hline Soilsealing, mn & GIS impervious area, mean \\
\hline Soilsealing, std & similar standard deviation \\
\hline popD, mn & GIS human population density \\
\hline PopD, std & similar standard deviation \\
\hline PopT & GIS total population in a catchment upstream of the study reach \\
\hline area & catchment area used for each study reach \\
\hline Nsurpfor, mn & GIS nitrogen surplus in forested parts of catchment, mean \\
\hline Nsurpfor, 2std & similar standard deviation \\
\hline Nusurpagr, mn & GIS nitrogen surplus in agricultural parts of catchment \\
\hline Nsurpagr, std & similar standard deviation \\
\hline livestock07sumheads & GIS total number of cattle heads \\
\hline livestock07dens & GIS cattle density \\
\hline rivslopemkm & $\begin{array}{l}\text { GIS, slope in } \mathrm{m} / \mathrm{km} \text { estimated along the line of the main stream with } \\
\text { linear regression, points every } 100 \mathrm{~m} \text { for a varable length of river } \\
\text { upstream of the study reach }\end{array}$ \\
\hline rivsloper2 & $\begin{array}{l}\text { GIS, r2 of the linear fit of the regression of height against position for } \\
\text { the slope }\end{array}$ \\
\hline meanQ & $\begin{array}{l}\text { mean annual discharge of each river at or near the studied reach, as } \\
\text { reported in the local assessment report }\end{array}$ \\
\hline \multicolumn{2}{|l|}{ Reach corridor land use } \\
\hline Percbuiltup & CORINE 111, 112, 121, 122, 131, 141, 142 \\
\hline Percarable & CORINE 211 \\
\hline percgrass & CORINE 231 \\
\hline Complexagric & CORINE 242 and 243 \\
\hline
\end{tabular}

Source

Muhar et al. (in prep)

Own assessment

Own assessment

GIS See S1 table 1

GIS see S1 table 1

GIS see S1 table 1

GIS see S1 table 1

GIS see S1 table 1

GIS see $S 1$ table 1

GIS see $\mathrm{S} 1$ table 1

GIS see $\mathrm{S} 1$ table 1

GIS see S1 table 1

GIS see $\mathrm{S} 1$ table 1

GIS see S1 table 1

GIS see S1 table 1

GIS see S1 table 1

GIS see S1 table 1

GIS see $\mathrm{S} 1$ table 1

GIS, own analysis

GIS, own analysis

From Muhar et al., in prep, and study site reports

All from GIS analyses, see references in Table 1 
percwood

percmarsh

percwater

CORINE 312, 313, 324, 333

CORINE 411 and 412

CORINE 511 and 512 
Supplementary material S2. Comparison of the value of ecosystem services of individual pairs of restored-unrestored river reaches. The most important components of each service are mentioned in the legend for each pair, and the primary is indicated with an *. Regulating services exclude flood risk reduction in the Narew because it could not be evaluated. Regulating services are expressed as net values and can be negative where current flood risk is a negative benefit as in the unrestored Drau. In the restored Regge flood risk reduction amounted to $1000 €$ ha $^{-1} \mathrm{y}^{-1}$; in 690 the Vääräjoki, flood risk reduction was -1 for the unrestored and $-2 € \mathrm{ha}^{-1} \mathrm{y}^{-1}$ for the restored reach (an increase in flood risk); In the restore Skjernå, flood risk reduction was $3 €$ ha- $^{-1} \mathrm{y}^{-1}$; in the unrestored Enns flooding was valued at -220 and in the restored Enns this was $-150 €$ ha $^{-1} \mathrm{y}^{-1}$; in the unrestored Drau flooding was valued at $-45 € \mathrm{ha}^{-1} \mathrm{y}^{-1}$; in the unrestored Becva flooding costs were estimated at -1900 whereas the restored reach had a benefit of $+1800 €$ ha $^{-1} \mathrm{y}^{-1}$; in the Morrumsån, finally, restoration did not affect flooding.
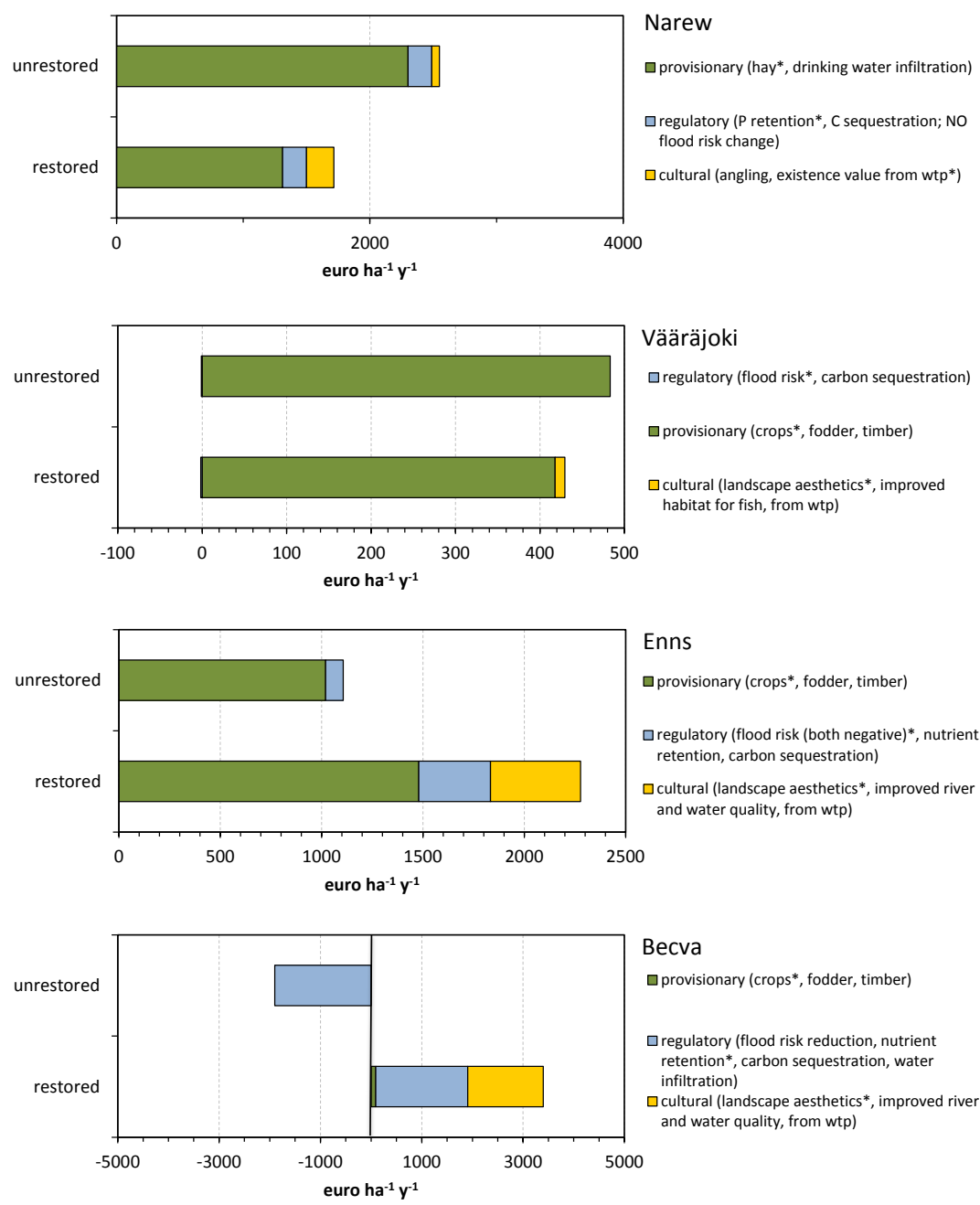

Regge

provisionary (hay*, drinking water infiltration*)

regulatory (P retention, flood risk reduction*) $\square$ cultural (kayaking, angling*, existence value
from wtp*)

\section{Vääräjoki}

$\square$ regulatory (flood risk*, carbon sequestration)

provisionary (crops", fodder, timber)

$\square$ cultural (landscape aesthetics*, improved habitat for fish, from wtp)

Enns

\section{provisionary (crops*, fodder, timber)}

Tregulatory (flood risk (both negative)*, nutrie retention, carbon sequestration) cultural (landscape aesthetics", improved river and water quality, from wtp
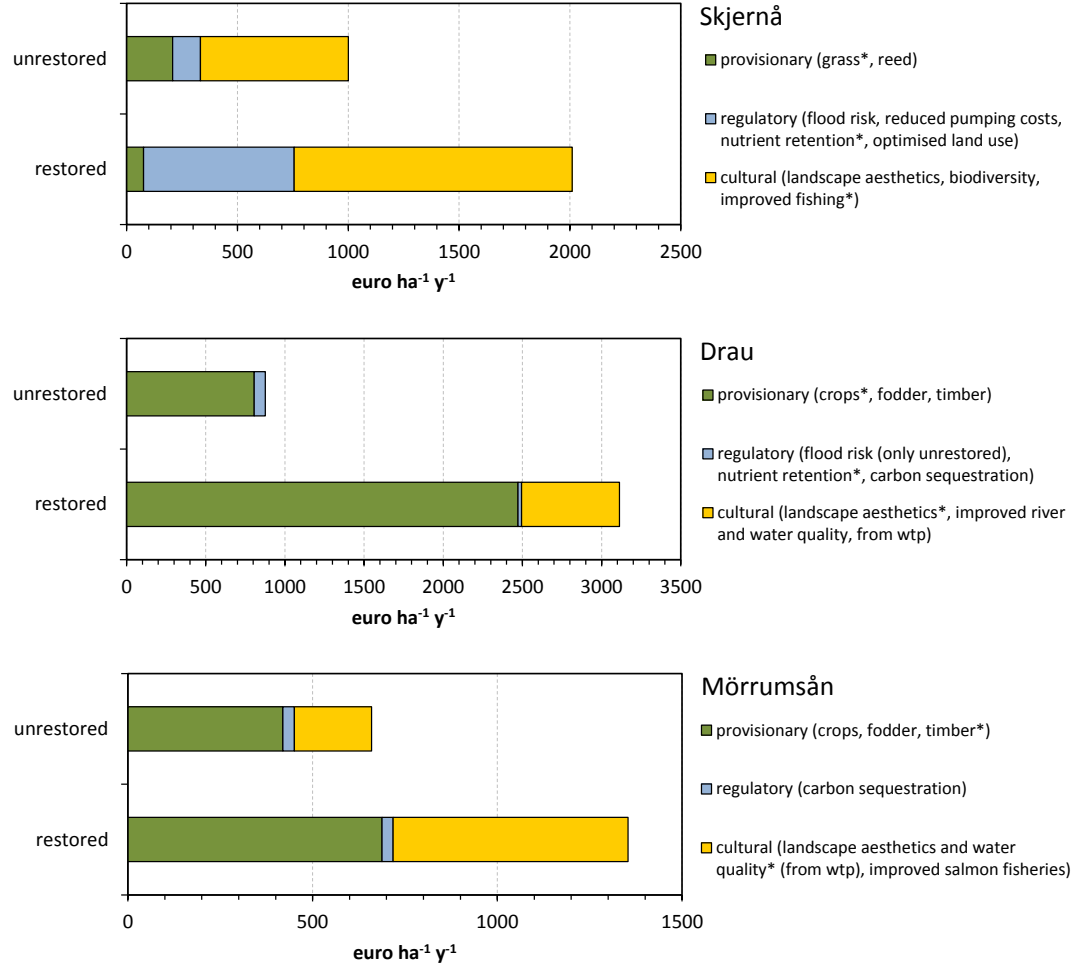

Skjernå

口 provisionary (grass*, reed) regulatory (flood risk, reduced pumping costs, cultural (landscape aesthetics, biodiversity improved fishing*)
cultural

regulatory (flood risk (only unrestored), nutrent Dcultural (landscape aesthetis"

\section{Mörrumsån} regulatory fflood risk reduction, nutrie 


\section{Assessing the societal benefits of river restoration using the ecosystem services approach}

Jan Vermaat et al. HYDR-D-15-00008

\section{RESPONSE TO REVIEWERS}

I have broken down the response into two categories, first I will address the main points made, and then I will deal with the detailed page-to-page points either written on the pages of a pdf (REV1) or included as comments in the word file (REV2). I have paraphrased the criticism in my own wording below. I have generally adopted minor editorial suggestions.

\section{REVIEWER 1}

\begin{tabular}{|c|c|}
\hline Main points of criticism & Response (line numbers of revision) \\
\hline $\begin{array}{l}\text { (a) Introduction and materials } \\
\text { and methods are very lengthy } \\
\text { and wordy }\end{array}$ & $\begin{array}{l}\text { Upon re-reading, they certainly were. REVIEWER } 2 \\
\text { had the same criticism. We hope to have written a far } \\
\text { more focused and concise revision. We have } \\
\text { completely rewritten large parts of the manuscript. }\end{array}$ \\
\hline $\begin{array}{l}\text { (b) Introduction needs to be more } \\
\text { focused, especially on } \\
\text { ecosystem services. It should } \\
\text { clarify the concept, give the } \\
\text { reasoning behind the work } \\
\text { done, and compare with other } \\
\text { existing methods. Methods } \\
\text { and criteria need to be } \\
\text { differentiated in a table. }\end{array}$ & $\begin{array}{l}\text { We have now tried to deal with (our interpretation of) } \\
\text { the concept of ecosystem services explicitly. New } \\
\text { version L } 81 \text {. We kept a brief bit on 'how-we-do-it' in } \\
\text { the introduction because it explains easier. } \\
\text { We have otherwise moved almost everything on } \\
\text { methods to the Methods section and included a table } \\
\text { specifying services and method used (New table 2) } \\
\text { We have not made an extensive comparison with } \\
\text { different approaches to estimate ecosystem services } \\
\text { because we feel this should be a concise paper and not } \\
\text { a textbook chapter. We refer to a recent textbook. We } \\
\text { do however argue why we monetize all, rather than } \\
\text { retain one or several other, different indicator scales (L } \\
176 \text { and further) }\end{array}$ \\
\hline $\begin{array}{l}\text { (c) Introduction needs to explain } \\
\text { (better) what the research } \\
\text { questions are and why }\end{array}$ & $\begin{array}{l}\text { We had our questions spelled out in the last paragraph } \\
\text { of the first version, so we think we know what our } \\
\text { questions are. We have now hopefully anchored them } \\
\text { better in the preceding text, also by weeding away } \\
\text { some of the side paths. }\end{array}$ \\
\hline $\begin{array}{l}\text { (d) Introduction should include } \\
\text { scale issues and have them } \\
\text { explicitly defined }\end{array}$ & $\begin{array}{l}\text { We now have a paragraph on scale. We distinguish } \\
\text { two scales: local (reach plus local floodplain) and } \\
\text { regional (catchment). We are aware of the fact that this } \\
\text { is qualitative, but see no way to reach a more } \\
\text { numerical break down. Vermaat et al ( } 2005 ; \text {. Ecol. }\end{array}$ \\
\hline
\end{tabular}




\begin{tabular}{|c|c|}
\hline & $\begin{array}{l}\text { Econ. 52: 229-237) have searched for correspondence in } \\
\text { scale breaks in spatial/environmental economics in } \\
\text { comparison to landscape ecological studies, but found } \\
\text { little holdfast on commonalities. Hein et al (2006, Ecol } \\
\text { Econ 57) use several more, but then had to stick to } \\
\text { administrative scales (municipality, province, } \\
\text { country), which then do not correspond to the scales of } \\
\text { the ecological and hydro-geological processes. We } \\
\text { therefore chose to limit us to these two scales. }\end{array}$ \\
\hline $\begin{array}{l}\text { (e) Discussion needs order: use } \\
\text { subheaders, group the text on } \\
\text { uncertainty and compare with } \\
\text { other methods }\end{array}$ & $\begin{array}{l}\text { Discussion has been regrouped under subheaders and } \\
\text { shortened. } \\
\text { We have not spent an elaborate paragraph on } \\
\text { methodological comparisons of ecosystem service } \\
\text { quantification methods. We feel that this is outside our } \\
\text { scope. Our study has a clear design comparing pairs of } \\
\text { similar, spatially distinct ecosystems, or pieces of } \\
\text { landscape. Very few others did so. See also last part of } \\
\text { our answer to comment (b). }\end{array}$ \\
\hline \multicolumn{2}{|l|}{$\begin{array}{l}\text { Pagewise (line numbers of first } \\
\text { version) }\end{array}$} \\
\hline $\begin{array}{l}\text { LL63-66 do not see link between } \\
\text { standards and documentation }\end{array}$ & Side path on standards and documentation removed \\
\hline $\begin{array}{l}\text { L } 69 \text { what is question and why, move } \\
\text { methods to methods }\end{array}$ & $\begin{array}{l}\text { In original version the questions came on L151. We } \\
\text { reorganized the methods (see b above) }\end{array}$ \\
\hline $\begin{array}{l}\text { L } 95 \text { insert scale of reach and } \\
\text { landscape elements }\end{array}$ & $\begin{array}{l}\text { We do so qualitatively in the text. Quantitatively this is } \\
\text { given in table } 1 \text {. An illustration is figure } 1 .\end{array}$ \\
\hline $\begin{array}{l}\text { L138-155 does this expose really } \\
\text { contribute? }\end{array}$ & We have deleted it \\
\hline $\begin{array}{l}\text { L190 services evaluated: move to } \\
\text { methods to explain which parameters } \\
\text { were used } \\
\text { L165 both groups of success } \\
\text { valuation should be described more } \\
\text { clearly }\end{array}$ & $\begin{array}{l}\text { We have systematically regrouped the methods on } \\
\text { service quantification and added a table }\end{array}$ \\
\hline $\begin{array}{l}\text { L240 which stats were used to test } \\
\text { what? }\end{array}$ & $\begin{array}{l}\text { We think we have written this down already in the first } \\
\text { version. Still, we have added some clarifying text to a } \\
\text { paragraph with a separate subheader. }\end{array}$ \\
\hline $\begin{array}{l}\text { L279 removing two outliers is not } \\
\text { acceptable. It biases the results }\end{array}$ & $\begin{array}{l}\text { Sure. And that is our main point. We have rephrased } \\
\text { the sentences to make this more clear. }\end{array}$ \\
\hline $\begin{array}{l}\text { L304 discussion should start with } \\
\text { ecosystem services and put them in a } \\
\text { wider context. }\end{array}$ & $\begin{array}{l}\text { We have considered this. We remain convinced that } \\
\text { we should start our discussion with our first question. } \\
\text { We have added subheaders to aid reading. }\end{array}$ \\
\hline $\begin{array}{l}\text { L345 this part of the discussion is } \\
\text { very general }\end{array}$ & We have removed it. \\
\hline
\end{tabular}




\section{REVIEWER 2}

\begin{tabular}{|c|c|}
\hline Main points of criticism & Response (line numbers of revision) \\
\hline $\begin{array}{l}\text { (a) Paper should be presented } \\
\text { more succinctly. Writing is } \\
\text { long and winding and } \\
\text { contains lots of jargon. }\end{array}$ & $\begin{array}{l}\text { The first author apologises for the lengthiness (I } \\
\text { should know better). We have tried to be brief and } \\
\text { reduce the jargon. Some economics jargon cannot be } \\
\text { evaded since this is a multidisciplinary paper. We were } \\
\text { also asked to be more explicit in places so the net } \\
\text { effect is that we removed some } 40 \text { lines. We now also } \\
\text { refer to a recent textbook (Bouma \& Van Beukering, } \\
\text { 2015) for a readable discussion of the different } \\
\text { disciplinary sides of ecosystem services assessment, } \\
\text { and their jargon. }\end{array}$ \\
\hline $\begin{array}{l}\text { (b) Paper could be better } \\
\text { organised }\end{array}$ & $\begin{array}{l}\text { We restructured the intro, methods and discussion, } \\
\text { mainly following reviewer } 1 \text {. We think it reads better } \\
\text { now. }\end{array}$ \\
\hline $\begin{array}{l}\text { (c) Strictly use 'habitat' and do } \\
\text { not mix with landscape } \\
\text { element }\end{array}$ & Done \\
\hline \multicolumn{2}{|l|}{$\begin{array}{l}\text { Pagewise (line numbers of first } \\
\text { version) }\end{array}$} \\
\hline $\begin{array}{l}\text { L180 normalizing habitat } \\
\text { provenance? }\end{array}$ & We think we have explained it better now. \\
\hline L202 why sediment not valued? & $\begin{array}{l}\text { We simply could not get enough sensible numbers on } \\
\text { this. If we could have estimated a reduced lifespan of a } \\
\text { downstream reservoir and corresponding hydropower } \\
\text { reduction it would have been feasible, but we could } \\
\text { not. }\end{array}$ \\
\hline $\begin{array}{l}\text { L253 How much of the difference is } \\
\text { due to the single outlier }\end{array}$ & $\begin{array}{l}\text { We actually answer(ed) this in the subsequent } \\
\text { sentence. Excluding the outlier does not remove the } \\
\text { significance }\end{array}$ \\
\hline L261 simplify sentences on PCA & Done \\
\hline $\begin{array}{l}\text { L273 ANOVA is on categorical } \\
\text { variables }\end{array}$ & $\begin{array}{l}\text { ANOVA, analysis of variance, can also be done on a } \\
\text { regression. A classical ANOVA can have both } \\
\text { factorial and continuous variables (covariates), and } \\
\text { GLM is exactly allowing that, mixing factorial and } \\
\text { continuous variables, plus an intercept to enhance } \\
\text { power. }\end{array}$ \\
\hline $\begin{array}{l}\text { L294 these numbers in the discussion } \\
\text { repeat the results }\end{array}$ & $\begin{array}{l}\text { Actually they were just a little different, but the } \\
\text { reviewer is correct, I should be more orthodox in } \\
\text { separating results from discussion. }\end{array}$ \\
\hline L306 wtp is actually a different point & $\begin{array}{l}\text { We reorganized the section following ref } 1 . \text { This } \\
\text { resolves the issue. }\end{array}$ \\
\hline
\end{tabular}




\begin{tabular}{|l|l|}
\hline $\begin{array}{l}\text { L324 limitation paragraph is too } \\
\text { long. }\end{array}$ & $\begin{array}{l}\text { We have pruned the paragraph a bit, but it has not } \\
\text { become much shorter. We feel all this has to be said, } \\
\text { and it would feel artificial to break up the paragraph. }\end{array}$ \\
\hline L334 fifth this is not a limitation & We now stop at fourth \\
\hline L351 condense paragraph & $\begin{array}{l}\text { We have greatly condensed this point and assimilated } \\
\text { it into an earlier paragraph (L315 and further) }\end{array}$ \\
\hline L370 last paragraph rambles & $\begin{array}{l}\text { We have removed most of it because it repeats from a } \\
\text { rather short discussion }\end{array}$ \\
\hline $\begin{array}{l}\text { Figures: standardize the a,b when } \\
\text { several figs form a panel. } \\
\text { Former fig 2 could be supplementary }\end{array}$ & Done \\
\hline $\begin{array}{l}\text { Table 1 delete the row on floodplain } \\
\text { slope }\end{array}$ & $\begin{array}{l}\text { Not done. This is original data obtained by ourselves } \\
\text { and entered into the PCA }\end{array}$ \\
\hline $\begin{array}{l}\text { Table 2 (table 3 in new version) drop } \\
\text { interpretation of the low r2 under } \\
\text { regulating services. Check your } \\
\text { numbers this seems to be wrong. }\end{array}$ & $\begin{array}{l}\text { There is nothing wrong with the outcome of the } \\
\text { statistical test. We are more cautious in interpreting } \\
\text { this, and keep in mind that variance in particularly this } \\
\text { dependent variable, regulating services, was massive } \\
\text { due to the Becva. It is not so odd that not much of that } \\
\text { variation is explained by the principal components, } \\
\text { and the little that is explained is due to restoration. }\end{array}$ \\
\hline
\end{tabular}

